\title{
Examining variation in the expression of tense/aspect to classify the Kikongo Language Cluster
}

\author{
Sebastian Dom and Koen Bostoen
}

\begin{abstract}
In this article we examine variation in the expression of tense and aspect (TA) in 23 modern and two historical Bantu language varieties belonging to Guthrie's B40, H10 and H30 groups in order to shed light on the internal classification of the Kikongo Language Cluster (KLC). We apply the Comparative Method to this specific set of morphological data to test a recent phylogenetic classification of the KLC. We identify eight widespread TA markers as shared retentions dating back to the period before the internal fragmentation of the KLC. Six of these are inherited from Proto-Bantu. Two other markers go back to Proto-Kikongoid and Proto-Kikongo. They confirm that the KLC constitutes a discrete clade within West-Coastal Bantu. We furthermore distinguish fourteen shared innovations that took place after the break-up of the last common ancestor of the KLC. These innovations provide corroborating evidence for three phylogenetic subgroups within the KLC, namely East, South and West, and for the fact that the latter subgroup falls apart in two discrete genealogical subunits. They furthermore testify to the horizontal transmission of TA features between subgroups. Such language convergence often correlates with relatively recent historical developments within the Lower Congo region and contributed to the multilayered constitution of the KLC.
\end{abstract}

Keywords: Kikongo Language Cluster, tense/aspect, language classification, language contact, Comparative Method 


\section{Introduction}

The Kikongo Language Cluster (henceforth KLC) is a disparate continuum of closely related Bantu languages spreading over large parts of four neighboring countries, i.e. southern Gabon, the southern part of the Republic of the Congo (RC), the Lower Congo province of the Democratic Republic of the Congo (DRC), and northern Angola including Cabinda. According to Lewis et al. (2014), a total population of approximately five million people in these four countries would speak a variety of Kikongo as their first language. Lumwamu (1973:13) estimates the number of Kikongo varieties at 51. In his updated version of Guthrie's (1971) referential Bantu classification, Maho (2009) lists up to 31 varieties as part of the 'H10 Kikongo Group'. For its comparative research, the KongoKing research group has selected some 32 different present-day Kikongo H10 regiolects, together with three B40 and four Kikongoid languages that are assumed to be sufficiently representative of the linguistic variation that exists within the KLC (see Map 1). ${ }^{1}$

Recent phylogenetic research by de Schryver et al. (this volume) has pointed out that 1) the KLC not only comprises language varieties from Guthrie's H10 group, but also from the B40, H30, H40 and L10 groups; 2) the KLC constitutes a discrete clade within 'West-Coastal Bantu'; 3) a number of H30, H40 and L10 languages within that clade, which de Schryver et al. (this volume) call 'Kikongoid', branch off before the core KLC; 4) the latter falls apart in four discrete subgroups, i.e. 'North', 'South', 'East', and 'West' (see Map 1); 5) a central contact zone, situated north and south of the unnavigable stretches of the Congo River and comprising the Kimanyanga and Kindibu varieties, developed between these four subgroups (see Map 1). ${ }^{2}$

Although the phylogenetic study by de Schryver et al. (this volume) is the most comprehensive classification of the KLC so far and also the first to be fully character-driven, it remains a first step in our historical comprehension of the KLC, since it is based on a limited dataset, viz. 92 items of so-called 'basic' or 'core' vocabulary. It thus needs to be tested against other datasets, both phonological and grammatical, either by applying new quantitative approaches or through the classical Comparative Method, in order to acquire a multi-level understanding of the internal constitution and evolution of the KLC. In this article, we focus on a grammatical piece of this layered puzzle by having a closer comparative look at one specific set of morphological data in Kikongo, namely tense/aspect markers.

Building on earlier MA research by the first author (Dom 2013), we compare here the most frequent tense/aspect (TA) markers in 25 varieties in order to assess to

1. KongoKing (2012-2016) is an interdisciplinary and interuniversity research project, led by the second author and funded by the European Research Council through Starting Grant No. 284126 and by the Special Research Fund of Ghent University. It aims at contributing to a better understanding of the origins and early history of the Kongo kingdom (www.kongoking.org). The current $\mathrm{PhD}$ research of the first author on tense and aspect in Kikongo is funded through a fellowship of the Research Foundation - Flanders (FWO).

2. The terms North, South, East, West and Central, i.e. with upper case, refer to genealogical subgroups. The terms northern, western, eastern, southern and central, i.e. with lower case, are purely geographic labels. 
what extent their variation within the KLC corresponds to the classification proposed by de Schryver et al. (this volume). We first try to identify shared retentions, which go back either to Proto-Bantu or to a more recent ancestral stage, possibly Proto-Kikongo, which we tentatively define here as the most recent common ancestor of the KLC. We then attempt to identify shared innovations, which are indicative of either genealogical subgrouping or contact-induced diffusion within the KLC.

Map 1. Phylogenetic classification of the Kikongo Language Cluster (de Schryver et al. this volume). Colored dots refer to the distinct subgroups: South (orange), West (green), North (red), East (blue), Central (black), Kikongoid (brown).

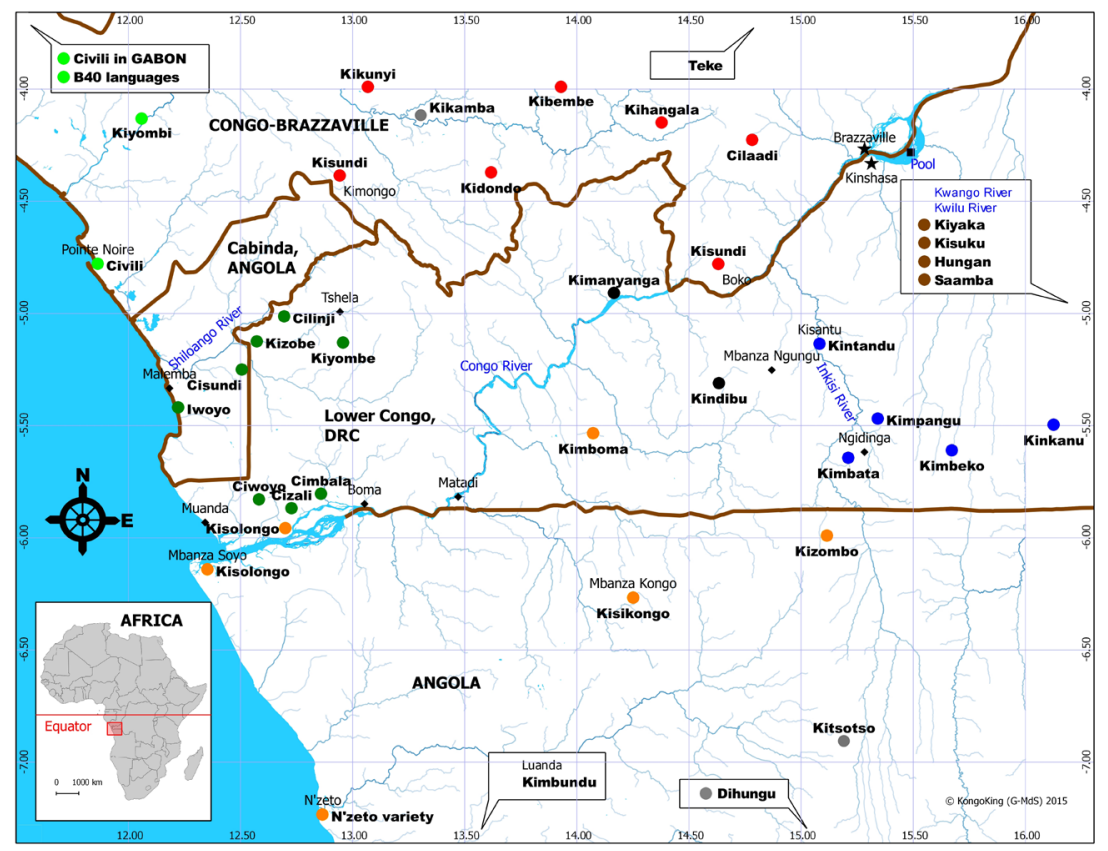

For this study, we draw on two kinds of data. The first type of evidence consists of new TA data collected by the first author during a linguistic fieldwork trip, which the KongoKing research team undertook in the Lower Congo Province of the DRC in the summer of 2012. This mission aimed at documenting lexical, phonological and grammatical variation in ten poorly documented Kikongo varieties, i.e. Kimbata, Kimbeko, Kinkanu, Cizali, Ciwoyo, Kisolongo, Kimpangu, Cimbala, Cilinji and Kizobe (De Kind et al. 2012). Extensive TA data were only gathered from the first six varieties. ${ }^{3}$ The second type of data originate from grammatical descriptions of 28 different 'doculects', i.e. linguistic varieties as they are documented in a given

3. We used a modified version of the questionnaire found in Tucker (1974) in which the most basic grammar components are treated. We updated it to sufficiently cover the rich TA categories of the Bantu languages, but it still was not comprehensive enough to allow for a detailed semantic analysis of TA in the languages considered here. 
resource (Cysouw \& Good 2013:342), representing 17 present-day varieties and two historical varieties. Because the phylogenetic study by de Schryver et al. (this volume) has pointed out that B40 varieties from Gabon are actually part of the West Kikongo subgroup, we have also systematically considered three B40 varieties in our comparative study. For one marker in Kindibu, namely the locative-infinitive construction expressing progressivity, we rely on corpus-based evidence presented in De Kind et al. (2015). This brings the total number of varieties to 26, even if no further description of TA in Kindibu is available to us and we also have not been able yet to carry out a full-fledged corpus-based study. Tables 1 and 2 give an overview of the two kinds of data as well as of the varieties and doculects covered in this study.

Table 1. Overview present-day varieties (1900 - present)

\begin{tabular}{lll}
\hline \multicolumn{2}{l}{ Grammatical descriptions } & KongoKing fieldwork 2012 \\
\hline Cilaadi (H16f) & (Jacquot 1982) & Ciwoyo (H16d) \\
Dihungu $^{4}$ & (Atkins 1954) & Cizali \\
Isangu (B42) & (Idiata 2006, Ondo-Mebiame 2000) & Kimbata \\
Iwoyo (H16d) & (Mingas 1994) & Kimbeko \\
Kibembe (H11) & (Kouarata 2015, Nsayi 1984) & Kinkanu \\
Kikamba (H112) & (Bouka 1989) & Kisolongo (H16a) \\
Kimanyanga (H16b) & (Laman 1912, & \\
& Makokila Nanzanza 2012) & \\
Kimboma (H16a) & (Kisilu Meso 2001) & \\
Kintandu (H16g) & (Butaye 1910, Daeleman 1966) & \\
Kisikongo (H16a) & (Ndonga Mfuwa 1995) & \\
Kisundi (H131) & (Kitambika 1994) & \\
Kitsootso & (Baka 1992) & \\
Kiyaka (H31) & (Van Den Eynde 1968) & \\
Kiyombe (H16c) & (Bittremieux 1927, De Clercq 1921) \\
Kizombo (H16h) & (Carter \& Makondekwa 1987, \\
Yilumbu (B44) & Mpanzu 1994) & \\
Yipunu (B43) & (Bomille 2013) \\
\hline
\end{tabular}

Table 2. Overview historical varieties (before 1900)

\section{Grammatical descriptions}

$\begin{array}{ll}\text { South Kikongo as spoken in Mbanza Kongo } & \text { (Bentley 1887, Brusciotto 1659, } \\ & \text { Guinness 1882a, Guinness 1882b) } \\ \text { West Kikongo as spoken in Kakongo } & \text { (Carrie 1888, Cuénot 1776) }\end{array}$

4. Dihungu and Kitsootso are included in neither Guthrie's (1971) classification nor in Maho's (2009) updated version. Baka (1992:1-2) argues that Kitsootso is more closely related to the Kikongo group (H10) than to Kiyaka (H31) based on the criterion of intercomprehensibility with Kisundi (H131), but not with Kiyaka (H31). Atkins (1954:146) considers Kitsootso to be a dialect of Dihungu. 
The quality and length of the grammatical descriptions are variable. For some varieties only one dissertation is available, whereas for others there is a dictionary, a grammar and one or more dissertations with a dedicated study of the verbal domain. Since we carried out neither extensive fieldwork nor text corpus analyses on the varieties considered here, our comparative study is unavoidably limited to those TA forms either documented in the literature or elicited during our field trip. Since not all varieties are equally well described, one always has to keep in mind that the lack of evidence for a given TA category or form in a given source is not necessarily proof of its absence in the variety concerned.

TA is expressed in three positions in Kikongo: i) preverbally, i.e. by means of auxiliaries or preverbal morphemes, ii) in the TA prefix slot of the conjugated verb, i.e. between the subject and object prefix slots, iii) in the final suffix slot of the conjugated verb. It is generally assumed that morphemes in the TA prefix slot have a different value, i.e. the encoding of tense, than those in verb-final position, i.e. the encoding of aspect (Nurse 2008:14-15).

We will mainly look at morphological means of expressing TA categories, since morphology is often better documented than syntactic strategies, such as the fronted infinitive construction (De Kind et al. 2015, Hadermann 1996). However, some auxiliary constructions are attested frequently enough to treat them in this paper. Furthermore, although tones undoubtedly play an important role, most sources lack a proper tonological description. Therefore, we could not systematically consider tone in the comparison of the different TA structures. We do mark them in the examples when tones are provided in the original source. For fieldwork data we only mark surface tone. Because the focus of this study is on the comparison of shared TA features, we also do not treat markers that occur only in one individual variety. It is not our purpose to provide an extensive account of all TA markers found in the KLC.

Given that most existing TA descriptions for Kikongo varieties are very general, it is also not our aim to make refined semantic analyses (which seems rather impossible with the available data). This study mainly focuses on the form and only to a minor degree on the semantics of TA categories in Kikongo. Even though we compare cognates with often similar meanings, these forms are still different morphemes in different varieties having (slightly) different uses. Moreover, since the specific function of a single morpheme within a single variety is not always fully understood yet, we have chosen to consider both prefixal and suffixal morphemes together as one circumfix expressing a given TA category. As a result, we will sometimes state that 'one' marker (i.e., circumfix) expresses both tense and aspect (e.g. 'present habitual'). However, we are fully aware that a more detailed analysis of the TA paradigms for each of all the 26 varieties should make a distinction between those morphemes dedicated to the expression of tense and those specifically used to convey aspect.

In the next section, we present those markers attested in present-day Kikongo varieties which are undoubtedly retentions from Proto-Bantu. We also discuss their distribution within the KLC as well as their main functions, which in some varieties deviate from their more common use. In section 2, we discuss two forms which are widely attested within the core varieties of the KLC, but are currently not attested 
outside of it, and can therefore be considered as shared retentions from the KLC's most recent common ancestor. Section 3 consists of two subsections: in $\S 3.1$ we present a total of 14 innovations and discuss both their geographical distribution and functions in the individual varieties. In $\$ 3.2$. we assess to what extent their current distribution can be accounted for by either genealogical inheritance or contact-induced spread in order to gain a better understanding of language evolution within the KLC. Conclusions are presented in the last section.

\section{Shared retentions inherited from Proto-Bantu}

In this section, we discuss widespread Kikongo TA markers whose origin is likely to be older than the emergence of the KLC. It concerns those present-day forms which are direct reflexes of morphemes that have been or could be reconstructed to Proto-Bantu. An overview of these TA markers is presented in Table 3. We not only take into consideration the actual number of varieties in which these TA markers are found, but also their distribution with regard to the phylogenetic subgroups identified by de Schryver et al. (this volume). 
Table 3. Overview of shared retentions inherited from Proto-Bantu

\begin{tabular}{|c|c|c|c|c|c|c|c|}
\hline & $\begin{array}{l}\text { Form } \\
\text { Function }\end{array}$ & $\begin{array}{c}\text {-a-B-a } \\
\text { P3 }\end{array}$ & $\begin{array}{c}\text {-a-B-idi } \\
\text { P1 }\end{array}$ & $\begin{array}{c}\text {-Ø-B-idi } \\
\text { PRF }\end{array}$ & $\begin{array}{l}\text {-Ø-B-a } \\
\text { PRS }\end{array}$ & $\begin{array}{l}\text {-ang- } \\
\text { IPFV }\end{array}$ & $\begin{array}{c}\text { mu INF } \\
\text { PROG }\end{array}$ \\
\hline \multirow[t]{7}{*}{ West $^{5}$} & Ciwoyo & $\mathrm{x}$ & $\mathrm{x}$ & & & $\mathrm{x}$ & \\
\hline & Cizali & $\mathrm{x}$ & $\mathrm{x}$ & $\mathrm{x}$ & $\mathrm{x}$ & $\mathrm{x}$ & $\mathrm{x}$ \\
\hline & Iwoyo & & & & & $\mathrm{x}$ & \\
\hline & Kiyombe & & & $\mathrm{x}$ & $\mathrm{x}$ & $\mathrm{x}$ & $\mathrm{x}$ \\
\hline & Isangu & & & & & & \\
\hline & Yipunu & & & & & & \\
\hline & Yilumbu & & & & & $\mathrm{x}$ & \\
\hline \multirow[t]{3}{*}{ North } & Kibembe & $\mathrm{x}$ & $\mathrm{x}$ & $\mathrm{x}$ & $\mathrm{x}$ & $\mathrm{x}$ & $\mathrm{x}$ \\
\hline & Kikamba & $\mathrm{x}$ & $\mathrm{x}$ & $\mathrm{x}$ & & & $\mathrm{x}$ \\
\hline & Cilaadi & & & $\mathrm{x}$ & $\mathrm{x}$ & $\mathrm{x}$ & \\
\hline \multirow{6}{*}{ South } & Dihungu & & $\mathrm{x}$ & $\mathrm{x}$ & & & \\
\hline & Kimboma & $\mathrm{x}$ & $\mathrm{x}$ & $\mathrm{x}$ & & $\mathrm{x}$ & \\
\hline & Kisikongo & $\mathrm{x}$ & $\mathrm{x}$ & $\mathrm{x}$ & & $\mathrm{x}$ & $\mathrm{x}$ \\
\hline & Kisolongo & $\mathrm{x}$ & $\mathrm{x}$ & $\mathrm{x}$ & & $\mathrm{x}$ & \\
\hline & Kitsootso & & $\mathrm{x}$ & $\mathrm{x}$ & & & $\mathrm{x}$ \\
\hline & Kizombo & $\mathrm{x}$ & $\mathrm{x}$ & $\mathrm{x}$ & & $\mathrm{x}$ & \\
\hline \multirow[t]{4}{*}{ East } & Kimbata & & & $\mathrm{x}$ & $\mathrm{x}$ & $\mathrm{x}$ & \\
\hline & Kimbeko & & & $\mathrm{x}$ & $\mathrm{x}$ & $\mathrm{x}$ & \\
\hline & Kinkanu & $\mathrm{x}$ & $\mathrm{x}$ & $\mathrm{x}$ & $\mathrm{x}$ & $\mathrm{x}$ & \\
\hline & Kintandu & & & $\mathrm{x}$ & $\mathrm{x}$ & $\mathrm{x}$ & $\mathrm{x}$ \\
\hline \multirow[t]{2}{*}{ Central } & Kisundi & & & $\mathrm{x}$ & & & $\mathrm{x}$ \\
\hline & Kimanyanga & $\mathrm{x}$ & $\mathrm{x}$ & $\mathrm{x}$ & $\mathrm{x}$ & $\mathrm{x}$ & $\mathrm{x}$ \\
\hline \multirow[t]{2}{*}{ Kikongoid } & Kiyaka $^{6}$ & $\mathrm{x}$ & $\mathrm{x}$ & $\mathrm{x}$ & & & \\
\hline & Total & 11 & 13 & 17 & 9 & 15 & 8 \\
\hline
\end{tabular}

5. When comparing the distribution of TA constructions between multiple varieties from different phylogenetic subgroups, we indicate these phylogenetic subgroups in the first column.

6. De Schryver et al. (this volume) consider Kiyaka (H31) as a Kikongoid language. It is included here to assess the time depth of certain widespread Kikongo TA features. Due to a lack of appropriate data, we have not been able to include in the sample Kisuku (H32) or Samba (L12a), two other Kikongoid languages. De Schryver et al. (this volume) do not consider the southern Kikongo varieties Kitsootso and Dihungu for a lack of sufficient basic vocabulary. 


\title{
1.1. -a-B-a
}

The common Bantu past circumfix -a-B-a (Nurse 2008:83) is attested in 11 Kikongo varieties as a marker of remote past (P3), as seen in (1) and (2).

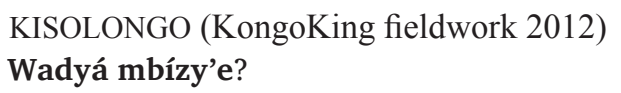

'Did you eat fish?'

(2) KIBEMBE (Kouarata 2015:95)

\author{
Béenu lwásala. \\ béenu lu-a-sal-a. \\ you $\quad \mathrm{SM}_{2 \mathrm{PL}}-\mathrm{P} 3$-work-P3 \\ 'You worked (a long time ago).'
}

The TA prefix -a- has a wide Bantu distribution. It appears in $84 \%$ of Nurse's (2008:82) language sample and is most often involved in the expression of past time reference (Nurse \& Philippson 2006:158ff.). Both the prefix -a- and the FV -a have been reconstructed to Proto-Bantu (Meeussen 1967:110, Nurse 2008:237, 261, Nurse \& Philipsson 2006:158).

In some varieties, this circumfix expresses other temporal meanings. It has been noted to have future time reference in Kikamba (North; Bouka 1989: pages not indicated), Kiyaka (Kikongoid; Van Den Eynde 1968:55), Kimanyanga (Central; Laman 1912:160) and Kisikongo (South; Bentley 1887:651). Laman (1912:277), for example, states that the future indicative -a-B-a, as in (3a), "denotes an action that is going to happen, without indicating how soon". As shown in (3b), -a-B-a may also express past time reference in Kimanyanga (Laman 1912:160, Makokila Nanzanza 2012:152). It is not clear how Kimanyanga speakers disambiguate between both meanings, since Laman (1912) does not consider the tonal patterns of these forms, and the -a-B-a future is not treated in Makokila Nanzanza (2012). In section 2.2., we further discuss this issue.

KIMANYANGA (Laman 1912:277, 276)

a. Mbazi yasumba nkombo.

mbazi i-a-sumb-a N-kombo.

tomorrow $\quad \mathrm{SM}_{1 \mathrm{SG}}$-FUT-buy-FV $\quad \mathrm{NP}_{9}$-goat

'Tomorrow I shall buy a goat.'

b. Nzambi wavanga zulu ye ntoto.

$\begin{array}{lllll}\mathrm{N} \text {-zambi } & \text { u-a-vang-a } & \varnothing \text {-zulu } & \text { ye } & \text { Ni-toto. } \\ \mathrm{NP}_{9} \text {-god } & \mathrm{SM}_{1}-\mathrm{P} 3 \text {-make-P3 } & \mathrm{NP}_{5} \text {-heaven } & \text { and } & \mathrm{NP}_{3} \text {-earth }\end{array}$

'God created heaven and earth.'

In Kitsootso and Dihungu, two Kikongo varieties spoken in Angola, the circumfix's function is restricted to the expression of the generic present (Atkins 1955:154, Baka 1992:105). It expresses generic (also called 'gnomic') situations (4a), and 
is therefore often used with stative verbs (4b), which inherently denote static, unchangeable states.

$$
\text { KITSOOTSO (Baka 1992:106) }
$$

a. Kù Múkábá yávwânlà.

ku Mukaba i-a-vwanl-a.

LOC $_{17}$ Mukaba SM $_{1 \mathrm{SG}}$-PRS-live-FV

'I live at Mukaba.'

b. Yá mbìzì yàwólà.

ya N-bizi i-a-wol-a.

$\mathrm{DEM}_{9} \quad \mathrm{NP}_{9}$-meat $\quad \mathrm{SM}_{9}$-PRS-be.bad-FV

'This meat is bad.'

The non-past uses of this TA marker have only been found in a very small number of sources each, not frequently enough to consider them as one of the circumfix's regular meanings. Explaining in detail the apparent polysemy of this TA marker - if it is not homonymy - goes beyond the scope of this article.

\section{2. -a-B-idi}

The TA marker -a-B-idi is attested in 13 varieties of the sample. It consists of two morphemes of Proto-Bantu origin, i.e. -a- discussed in the previous section and the reflex of the Proto-Bantu suffix *-ide (Bastin 1983:2, 4, Meeussen 1967:110, Nurse 2008:264, Nurse \& Philippson 2006:182-183). The circumfix is a common Bantu past tense marker (Nurse 2008:83, Nurse \& Philippson 2006:162-63, 181). In Kikongo, it most often expresses past time reference, traditionally categorized as hesternal past (P2) (Comrie 1985:88, Dahl 1985:126, Nurse 2008:22).

The suffix has a number of different realizations in the KLC, viz. -idi, -ili, -izi and -iri, some of which will be discussed below as regional features. The variation pertains solely to the reflex of the intervocalic consonant. In all Kikongo varieties, the first vowel *-i has triggered progressive assimilation on the second vowel *-e, resulting in -iCi (Bastin 1983:49). In front of the final high front vowel, most varieties have [d] or [r] as regular allophone of [1]. The example in (5) illustrates the use of this TA circumfix in Kisikongo. The suffix here undergoes vowel height harmony under the influence of the mid-vowel of the root (Bastin 1983:13-16, Hyman 1999).

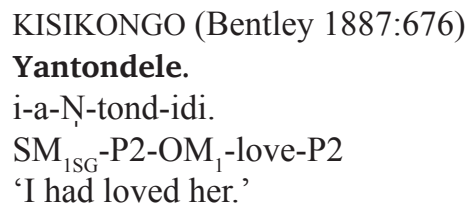




\section{3. - Ø-B-idi}

The TA marker consisting of a 'zero' morpheme in the TA prefix slot and a reflex of the Proto-Bantu final *-ide has a wide distribution in the Bantu domain (Bastin 1983:9-10, Nurse 2008:156, 264, Nurse \& Philippson 2006:181-3). ${ }^{7}$ Within the KLC, it is the most frequent TA marker having 17 attestations. In line with Brisard \& Meeuwis' (2009) analysis of the FV -i in Lingala, this circumfix seems to express the present perfect with focus on the end state in Kikongo, as shown in (6). When combined with stative verbs, such as -tonga 'be tired' in (7), the marker thus focuses on the present state of the subject. Note that in (7) the final is once again subject to vowel harmony triggered by the mid vowel [o] of the verb root.

$$
\begin{aligned}
& \text { KIMBATA (KongoKing fieldwork 2012) } \\
& \text { Íngá, mu kyeléká, tútidi lo. } \\
& \text { inga, mu ki-eleka Ø-Ø-tut-idi lo. } \\
& \text { yes } \quad \mathrm{LOC}_{18} \quad \mathrm{NP}_{7} \text {-truth } \quad \mathrm{SM}_{1} \text {-PRS-pound-PRF } \quad \text { PRON }_{11} \\
& \text { 'Yes, she has definitely pounded it (luku 'cassava'). }
\end{aligned}
$$

\section{KISOLONGO (KongoKing fieldwork 2012)}

\section{Mbutááme osádídi lumbu kya mvímba, otóngele.}

$$
\begin{aligned}
& \text { N̦-buta-ame o-Ø-sal-idi } \quad \text {-lumbu ki-a } \quad \mathrm{N} \text {-vimba, } \\
& \mathrm{NP}_{1} \text {-mother-POSS }{ }_{1 \mathrm{SG}} \mathrm{SM}_{1} \text {-PRS-work-PRF } \mathrm{NP}_{7} \text {-day } \mathrm{PP}_{7} \text {-CON } \mathrm{NP}_{9} \text {-whole } \\
& \text { o-Ø-tong-idi. } \\
& \mathrm{SM}_{1} \text {-PRS-be.tired-PRF } \\
& \text { 'My mother has worked all day, she's tired.' }
\end{aligned}
$$

In a number of Kikongo varieties, the TA marker - $\emptyset$-B-idi also expresses (remote) past. As discussed in section 3.1.1., this has resulted from the loss of the -a- prefix, which has led to a pair of formally identical markers expressing more than one TA category.

\section{4. - Ø-B-a}

The FV -a is often labeled 'neutral' (Nurse 2008:261, Nurse \& Philippson 2006:179). Meeussen (1967:110) describes it as occurring "in most forms". Such descriptions seem to imply that it serves no functional purpose. However, it contrasts with other final suffixes such as subjunctive -e or past/perfect -idi. It has therefore been proposed to label final -a as 'indicative' (Nurse 2008:261, Nurse \& Philippson 2006:179). However, we do not adopt the term here since the TA categories expressed by e.g. the final -idi also fall under the indicative mood. The Kikongo TA marker - $\varnothing$-B-a most likely goes back to Proto-Bantu (Nurse 2008:236, 261, Nurse \& Philippson 2006:166).

7. We do not want to make any theoretical claims by analyzing a prefixally unmarked verb as having a 'zero' morpheme. Some will analyze this simply as a verb with an unmarked or empty prefix slot, while others might prefer to analyze this as a 'zero' morpheme, alternating paradigmatically with other, overt TA markers, such as -a- or -ku-. 
This conjugation most frequently expresses present tense in Kikongo. The zero present is widespread throughout the Bantu languages (Nurse 2008:118, Nurse \& Philippson 2006:164). Interestingly, only 9 varieties in the sample have this present tense marker. In the remaining 14 Kikongo varieties a number of new present tense forms have developed, some of which will be presented further on as in-group innovations.

'Present tense' has to be understood as a flexible category, best defined broadly as a period of variable length located between past and future (Nurse 2008:116). The zero present incorporates the present progressive (8), habitual/continuous present (9) and generic present (10).

KIMBEKO (KongoKing fieldwork 2012)

\section{Khí badyá bana?}

khi ba-Ø-di-a ba-ana?

what $\mathrm{SM}_{2}$-PRS-eat-FV $\quad \mathrm{NP}_{2}$-child

'What are the children eating?'

(9) KIMBATA (KongoKing fieldwork 2012)

Kyó kindendi kiyakálá thángu zaakulu kálééka.

kyo ki-ndendi ki-yakala N-tangu zi-aakulu ka-Ø-leek-a.

$\mathrm{DEM}_{7} \quad \mathrm{NP}_{7}$-child $\quad \mathrm{NP}_{7}$-man $\quad \mathrm{NP}_{10}$-time $\quad \mathrm{PP}_{10}$-all $\quad \mathrm{SM}_{1}$-PRS-sleep-FV

'This boy sleeps all the time.'

(10) KINTANDU (Daeleman 1966:258)

Nzó zizinúka nsudi kabákótá zó ko.

\begin{tabular}{|c|c|c|c|}
\hline N-zo & zi-Ø-zinuk-a & $\mathrm{N}$-sudi & ka-ba-Ø-kot-a \\
\hline $\mathrm{NP}_{10}$-house & $\mathrm{SM}_{10}$-PRS-smell-FV & $\mathrm{NP}_{9}$-bad.smell & NEG-SM - -PRS-enter-FV \\
\hline zo & ko. & & \\
\hline $\mathrm{PRON}_{10}$ & NEG & & \\
\hline
\end{tabular}

\section{5. - -ang-}

According to Sebasoni (1967:134), the common Bantu suffix -ang-, also attested as -ag- or -ak-, expresses a number of related meanings such as continuous, habitual, iterative, frequentative, repetitive, intensive, and durative, which can be subsumed under the more general TA category of 'imperfective' (Nurse 2008:138, Nurse \& Philippson 2006:190). It is attested in 15 of the varieties studied here and occurs in combination with the present (11), future (12) or past (13) tense.

(11) CIZALI (KongoKing fieldwork 2012)

Nkháma sába cyandi nséke cikééle, yikwénda kuntálánga káka kadíka lumbu.

nkhama $\varnothing$-saba ci-andi N-seke ci-Ø-kal-izi

despite $\quad \mathrm{NP}_{7}$-house $\mathrm{PP}_{7}$-POSS $\mathrm{NP}_{9}$-distance $\mathrm{SM}_{7}$-PRS-be-PRF

i-Ø-kwend-a ku-N̦-tal-ang-a kaka kadika Ø-lumbu.

$\mathrm{SM}_{1 \mathrm{SG}}$-PRS-go-FV $\mathrm{NP}_{15}-\mathrm{OM}_{1}$-see-IPFV-FV only every $\mathrm{NP}_{7}$-day

'Despite his house being so far away, I just visit him every day.' 


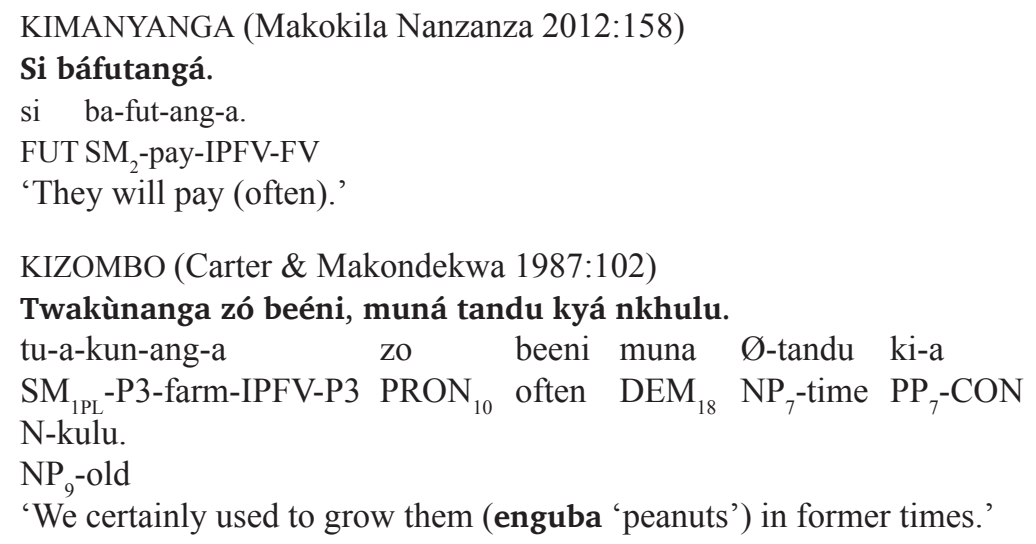

\section{6. $\mathrm{mu} \mathrm{INF}$}

The use of a locative element in the expression of progressivity is cross-linguistically common (Bybee et al. 1994:129-31). This is also the case in Bantu, where the construction 'be+locative+verbal noun' has been reconstructed for Proto-Bantu (Bastin 1989a+b, Nurse 2008:249). Nurse \& Philippson (2006:193) state that "since this is a process which occurs easily, quickly, and naturally, it could have occurred independently before, during, and many times since (and before) Proto-Bantu". Within the KLC, it is found in a number of geographically distant varieties, which leads us to assume that it goes back to at least Proto-Kikongo (De Kind et al. 2015). Given its occurrence outside the KLC, even in immediately neighboring groups, this construction cannot be considered as a shared innovation inherited from the KLC's most recent common ancestor. If not to Proto-Bantu, it certainly goes back to an older ancestral stage.

The construction has a number of reflexes in present-day Kikongo varieties. Some have retained the skeletal structure 'be+locative+verbal noun', such as Kindibu in (14) where the components of the structure have been reshuffled into the structure 'locative+verbal noun+be'. Others, such as Kiyombe in (15), have reduced the class 18 locative marker to a homorganic syllabic nasal, in line with the common Kikongo process of prefix syncope (Bostoen \& de Schryver 2015), and integrated it as a grammaticalized TA marker in the conjugated verb. In the latter variety, the morphological reduction has been accompanied with a semantic change whereby the progressive meaning has evolved into a generic present reading (15a) (see also Hadermann 1996:161). The present progressive is now expressed by means of the fronted infinitive construction in Kiyombe (De Kind et al. 2015, Hadermann 1996), with the finite verb taking the nasal present marker (15b). 
(14) KINDIBU (De Kind et al. 2015)

Wau una wantu mu leka bena, mbeni andi wizidi.

wau una wa-ntu mu $\varnothing$-lek-a ${ }^{8}$ be-na, N̦-beni andi

$\mathrm{DEM}_{14}$ ADV NP $\mathrm{N}_{2}$-person $\mathrm{LOC}_{18} \mathrm{NP}_{15}$-sleep-FV $\mathrm{SM}_{2}$-be $\mathrm{NP}_{3}$-enemy $\mathrm{POSS}_{1}$ u- $\varnothing$-iz-idi.

$\mathrm{SM}_{1}$-PRS-come-PRF

'While the people were sleeping, his enemy came.'

(15) KIYOMBE (De Clercq 1921:36)

a. Ndinsumba.

ndi-N-sumb-a.

$\mathrm{SM}_{1 \mathrm{SG}}-\mathrm{PRS}-\mathrm{buy}-\mathrm{FV}$

'I buy.'

b. Sumba ndinsumba.

$\varnothing$-sumb-a ndi-N-sumb-a.

$\mathrm{NP}_{15}$-buy-FV $\quad \mathrm{SM}_{1 \mathrm{SG}}$-PRS-buy-FV

'I am buying.'

An intermediate stage in the morpho-phonological reduction from 'be+locative+infinitive' to a simple nasal is found in Kisundi. The locative prefix is still preserved in its entirety, but has become prefixed onto the verb stem, and the auxiliary has been deleted (16). This grammaticalization is accompanied here by a semantic shift from progressive to near future. In Kikamba, progressivity is expressed by means of a complex formative consisting of an -a- prefix followed by the locative morpheme -mu- (17).

(16) KISUNDI (Kitambika 1994:138)

Tùmúsàlà.

tu-mu-sal-a.

$\mathrm{SM}_{1 \mathrm{PL}}$-FUT-work-FV

'We will (soon) work.'

(17) KIKAMBA (Bouka 1989: pages not numbered)

Wamumaka

u-a-mu-mak-a.

$\mathrm{SM}_{1}$-PRS-PROG-climb-FV

'He is climbing.'

8. The $\mathrm{NP}_{15}$ of the infinitive is one of the noun prefixes which was reduced to zero in many Kikongo varieties, as extensively discussed in Bostoen \& de Schryver (2015:162ff). 


\section{Shared retentions inherited from Proto-Kikongo}

In this section, we discuss two TA markers whose distribution is, as far as we can judge today, restricted to the KLC, namely the final -idingi and the future marker si. Not only are they found in several present-day Kikongo varieties, i.e. 15 and 10 respectively, but both are also attested in the different phylogenetic subgroups established by de Schryver et al. (this volume). We therefore consider them as retentions inherited from the most recent common ancestor of the KLC, i.e. Proto-Kikongo. Being widespread within the KLC, but absent from more distantly related West-Coastal Bantu languages, both can be considered to be shared morphological innovations undergone by Proto-Kikongo before the emergence of the KLC. They corroborate the phylogenetic classification of the KLC as a discrete clade within West-Coastal Bantu.

Table 4. Overview of shared retentions inherited from Proto-Kikongo

\begin{tabular}{|c|c|c|c|}
\hline & $\begin{array}{l}\text { Form } \\
\text { Function }\end{array}$ & $\begin{array}{c}\text {-idingi } \\
\text { P1 }\end{array}$ & $\begin{array}{c}\text { si } \\
\text { FUT }\end{array}$ \\
\hline West & $\begin{array}{l}\text { Ciwoyo } \\
\text { Cizali } \\
\text { Iwoyo } \\
\text { Kiyombe } \\
\text { Isangu } \\
\text { Yipunu } \\
\text { Yilumbu }\end{array}$ & $\begin{array}{l}\mathrm{x} \\
\mathrm{x}\end{array}$ & $\mathrm{x}$ \\
\hline North & $\begin{array}{l}\text { Kibembe } \\
\text { Kikamba } \\
\text { Cilaadi }\end{array}$ & $\mathrm{x}$ & $\mathrm{x}$ \\
\hline South & $\begin{array}{l}\text { Dihungu } \\
\text { Kimboma } \\
\text { Kisikongo } \\
\text { Kisolongo } \\
\text { Kitsootso } \\
\text { Kizombo }\end{array}$ & $\begin{array}{l}\mathrm{x} \\
\mathrm{x} \\
\mathrm{x} \\
\mathrm{x} \\
\mathrm{x}\end{array}$ & $\begin{array}{l}x \\
x\end{array}$ \\
\hline East & $\begin{array}{l}\text { Kimbata } \\
\text { Kimbeko } \\
\text { Kinkanu } \\
\text { Kintandu }\end{array}$ & $\begin{array}{l}\mathrm{x} \\
\mathrm{x} \\
\mathrm{x} \\
\mathrm{x}\end{array}$ & $\begin{array}{l}\mathrm{x} \\
\mathrm{x} \\
\mathrm{x} \\
\mathrm{x}\end{array}$ \\
\hline Central & $\begin{array}{l}\text { Kisundi } \\
\text { Kimanyanga }\end{array}$ & $\begin{array}{l}\mathrm{x} \\
\mathrm{x}\end{array}$ & $\begin{array}{l}\mathrm{x} \\
\mathrm{x}\end{array}$ \\
\hline Kikongoid & Kiyaka & $\mathrm{x}$ & \\
\hline & Total & 15 & 10 \\
\hline
\end{tabular}




\subsection{Final -idingi}

This historically compound TA marker has not been reconstructed to Proto-Bantu, but it is widespread in the KLC. It is found in 15 varieties of the sample belonging to the four different phylogenetic subgroups. This indicates that the morpheme is most likely a retention from an older stage of the KLC, possibly Proto-Kikongo. It can combine with either a 'zero' morpheme in the TA slot (18), or with the -a- prefix (Bentley 1887:650 and Guinness 1882b:78 for Kisikongo, Laman 1912:160 for Kimanyanga), as shown in (19). The TA marker most often expresses past time reference, traditionally labeled as hodiernal past (P1) (Comrie 1985:87, Dahl 1985:125, Nurse 2008:90). The complex final is a combination of -idi and -ang-, in which the imperfective morpheme bisects the perfect marker. The concatenation of these two morphemes is not unique for Kikongo, but it is rather rare elsewhere in Bantu (Nurse 2008:263). Moreover, as far as we known, it is not attested in the KLC's immediate neighbors.

CIZALI (KongoKing fieldwork 2012)

Cínsyá usalizíngi unsúka wáwu?

$\begin{array}{llll}\text { cinsya } & \mathrm{u}-\varnothing \text {-sal-izingi } & \mathrm{u}-\mathrm{N} \text {-suka } & \text { wawu? } \\ \text { what } & \mathrm{SM}_{2 \mathrm{SG}}-\mathrm{P} 1 \text {-do-P1 } & \mathrm{AUG}_{3}-\mathrm{NP}_{3} \text {-morning } & \mathrm{DEM}_{3}\end{array}$

'What did you do this morning?'

(19) KISIKONGO (Bentley 1887:650)

Yasumbidinge.

i-a-sumb-idingi.

$\mathrm{SM}_{1 \mathrm{SG}}$-P1-buy-P1

'I had been buying.'

In all present-day Kikongo varieties, the incorporation of -ang- into -idi has resulted in the full assimilation of its vowel, viz. /-id-ang-i/ $>$ /-id-ing-i/. A possible intermediate stage, in which the open vowel /a/ of the imperfective suffix is raised to /e/, is attested in Brusciotto's 1659 grammar of the historical South Kikongo variety where the following past tense endings are listed: -lengi, -engi and -dingi (cf. Guinness 1882a:78).

\subsection{Preverbal si}

The TA marker si expresses future time reference. It is also found as sa in Kimbata, Kintandu (21) and Kibembe and as se in Kisikongo (22). The morphosyntactic status of this marker is not clear. In some sources the morpheme is written separately from the conjugated lexical verb, as in (20), whereas in others it is prefixed onto the verb structure, as in (21). More research should elucidate whether the morpheme is a preverbal or prefixal marker. 
(20)

KINTANDU (Daeleman 1966:305)

Mbasi ganá nsúsú ntete gá sá tuteláma.

mbasi gana N-susu N-tete ga sa tu-telam-a.

tomorrow $\mathrm{DEM}_{16} \mathrm{NP}_{9}$-rooster $\mathrm{NP}_{9}$-first $\mathrm{LOC}_{16}$ FUT $\mathrm{SM}_{1 \mathrm{PL}}$-get.up-FV

'Tomorrow, at the rooster's first crow, we will get up.'

(21) KISIKONGO (Ndonga Mfuwa 1995:365)

Sèn'túng(à) énzò.

se-N-tung-a e-N-zo.

FUT-SM ${ }_{1 \mathrm{SG}}$-build-FV $\quad \mathrm{AUG}_{9}-\mathrm{NP}_{9}$-house

'I will build the house.'

The verb can also be inflected with the TA prefix -a-, as shown in (22). Although the prefix -a- is often described as encoding past time reference (see section 1.1. above), its occurrence in non-past markers (also see the discussion of Kimanyanga at the end of section 1.1.) strongly suggests that a semantic reanalysis of the prefix's function in some Kikongo varieties is in order. In those varieties where we find -a- in both past and future tenses, a better description would be to define the -amorpheme as a marker of temporal remoteness, i.e. its function is to locate the event denoted by the verb in a conceptually distal temporal domain (Botne 2014:18, and cf. Botne \& Kershner 2008). Whether this remote domain is situated in the future or the past is then elaborated through contextual information or other TA material in the construction.

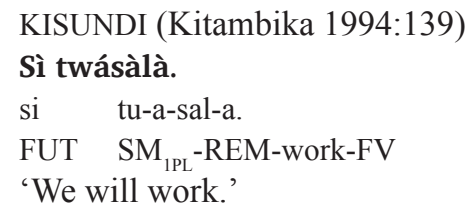

The future construction occurs in 10 varieties of the language sample scattered across different phylogenetic subgroups of the KLC. This indicates that it might also be a shared innovation that took place at the ancestral stage of Proto-Kikongo and corroborates the phylogenetic status of the KLC as a discrete clade, although the low number of varieties having retained si and the vowel variation (si, se, sa) do not preclude the possibility of different diachronic scenarios. Moreover, it is not yet clear what could be the lexical source of this preverbal future marker. There are a number of possibilities, such as the Proto-Bantu verbs *-cád- 'do' or the defective quotative *-ti 'say'. Neither 'do' nor 'say' are cross-linguistically common source verbs, although some languages do have a future marker that grammaticalized from 'do' (Bybee et al. 1994:253).

\section{Shared innovations indicative of subgrouping within the KLC}

In this section, we present a number of innovative TA features which are characteristically Kikongo, but whose distribution within the KLC indicates that they occurred posterior to Proto-Kikongo. In that respect, they are possibly 
indicative of subgrouping within the KLC. However, because some of the innovations observed are parallel and others in all likelihood contact-induced, we first present all innovations without any claims about their significance for the internal classification of the KLC. Moreover, some of these innovations are clearly related to one of the TA markers already discussed above. They either underwent characteristic morpho-phonological changes or developed new meanings. Finally, other TA markers having a limited distribution within the KLC are possibly just apparent innovations. We verify and discuss whether they are retentions of older Proto-Bantu morphemes that have only been conserved in one subgroup. In section 3.2., then, we discuss the historical significance of each of these TA features.

\subsection{Overview of innovations}

\subsubsection{Loss of TA prefix -a-}

This innovation is attested in the eastern varieties Kintandu, Kimbata and Kimbeko as well as in the western varieties Kiyombe and Iwoyo. As a result of the loss of the -a- prefix, both the perfect and P2 have the same form, - $\emptyset$-B-idi (23), as well as P3 and the present, - $\varnothing$-B-a (24). In other varieties, P2 and P3 have the forms -a-B-idi and -a-B-a respectively (see sections 1.1. and 1.2.).

(23) KIMBEKO (KongoKing fieldwork 2012)

a. Mwaná ye tááta bafwánéni.

mu-ana ye Ø-taata ba-Ø-fwan-an-idi.

$\mathrm{NP}_{1}$-child and $\mathrm{NP}_{1 \mathrm{a}}$-father $\mathrm{SM}_{2}$-PRS-resemble-RECP-PRF

'The child and (his) father resemble each other.'

b. Zǒnó, yédí ku yatá, yisumbídí mbisí.

zono, i-Ø-i-idi ku Ø-yata, i-Ø-sumb-idi N-bisi.

yesterday $\quad \mathrm{SM}_{1 \mathrm{SG}}$-P2-go-P2 $\quad \mathrm{LOC}_{17} \quad \mathrm{NP}_{5}$-village $\quad \mathrm{SM}_{1 \mathrm{SG}}$-P2-buy-P2 $\quad \mathrm{NP}_{9}$-meat 'Yesterday, I went to the village and bought meat.'

(24) KIMBATA (KongoKing fieldwork 2012)

a. Inga, mu phimpa ímóna.

inga, mu N-pimpa i-Ø-mon-a.

yes $\quad \mathrm{LOC}_{18} \quad \mathrm{NP}_{9}$-dark $\quad \mathrm{SM}_{1 \mathrm{SG}}$-PRS-see-FV

'Yes, I see in the dark.'

b. Thamá ibútúka.

thama i-Ø-butuk-a.

long.ago $\mathrm{SM}_{1 \mathrm{SG}}$-P3-be.born-P3

'I was born a long time ago.'

Although these TA categories are morphologically marked in identical ways, they are formally disambiguated by means of different SMs and tone patterns. The singular SMs of the speech act participants in particular manifest the variation shown in Table 5. The occurrence of multiple SMs for the 1SG, 2SG and 3SG or class 1 is found throughout the KLC and is furthermore attested elsewhere in Bantu (see for example Kipacha 2006 on southern Swahili dialects). The historical 
conditioning and function of this allomorphy in different Kikongo varieties are still unclear (cf. Bastin 2006:27-28). In any event, due to the -a- loss, the variation seems to have taken on the additional role of formally disambiguating between identical TA markers.

Table 5. Variation SMs

\begin{tabular}{lll}
\hline & PRS/P2/P3/FUT & PRF/P1 \\
\hline $\mathrm{SM}_{1 \mathrm{SG}}$ & ndi-/i- & $\mathbf{N}-$ \\
$\mathrm{SM}_{2 \mathrm{SG}}$ & $\mathbf{u}-$ & $\boldsymbol{\emptyset}-$ \\
$\mathrm{SM}_{1}$ & $\mathbf{u}-$ & $\boldsymbol{\emptyset}$ \\
\hline
\end{tabular}

From the Kiyombe source we could only establish the variation of the $\mathrm{SM}_{1 \mathrm{SG}}$ ndivs. $\mathbf{N}$ - (the TA paradigm is illustrated only with examples of the 1SG and 1PL; De Clercq 1921:36-39). All other varieties with -a- loss have $\mathrm{SM}_{1 \mathrm{SG}}$ i- instead of ndi-. In Kintandu, Kimbeko and Kimbata, the group of SMs in the first column, $\mathbf{i}-/ \mathbf{u}-/ \mathbf{u}-$, is used in combination with all TA categories except for the perfect and P1, which take the SMs in the second column, $\mathbf{N}-/ \varnothing-/ \emptyset$-. In Kiyombe, there is an alternation in SMs between the perfect and P2, as shown in (25). Hence, although the perfect and P2 are encoded by the same marker - $\emptyset$-B-idi, the former takes $\mathbf{N}$ (25a), and P2 ndi- (25b). The underlying nasal SM in (25a) has been lost in the surface realization, but its affricativizing effect on the voiceless fricative of the verb root remains visible. ${ }^{9}$

(25) KIYOMBE (De Clercq 1921:37)

a. Tsumbidi.

N-Ø-sumb-idi.

$\mathrm{SM}_{1 \mathrm{SG}}$-PRS-buy-PRF

'I have bought.'

b. Ndísúmbídi.

ndi-Ø-sumb-idi.

$\mathrm{SM}_{1 \mathrm{SG}}-\mathrm{P} 2$-buy-P2

'I bought.'

The loss of -a- in Kiyombe has not resulted in identical present and P3 forms, as the present is not expressed by a "null" prefix but by means of a nasal formative that grammaticalized from the 'be+locative+infinitive' construction (see section 1.6), i.e. -N-B-a, which is different from the P3 circumfix - $\emptyset$-B-a.

(26) KIYOMBE (Bittremieux 1927:838-39)

a. Ndinsumba.

ndi-N-sumb-a.

$\mathrm{SM}_{1 \mathrm{SG}}$-PRS-buy-FV

'I buy/am buying.'

9. The post-nasal affrication of voiceless fricatives is a common sound change, both in the KLC and in Bantu more generally (Hyman 2003:51, Kerremans 1980:172-173, Mabiala 1999). 


\section{b. Ndisûmba.}

ndi-Ø-sumb-a.

$\mathrm{SM}_{1 \mathrm{SG}}$-P3-buy-P3

'I bought.'

The same holds for Iwoyo, although in this variety the present marker is the formative -i- (Mingas 1994:311), and the P3 marker is - Ø-B-a. Without giving any further details on SM alternation, Mingas (1994:317) remarks that in P3 the SM is ku- instead of the regular u-. Moreover, P1 and P2, having the identical TA marker - $\varnothing$-B-izi (cf. section 3.1.8. below for a discussion on the innovation of the common perfect marker having become a dedicated past marker in some varieties), also have the same SMs and are thus solely distinguished by a different tone pattern. This is also the case for the present and P3 in Kimbata (24), Kintandu and Kimbeko. As we can see in the Iwoyo example in (27), the final of P2 is completely high, whereas in P1 only the last vowel carries a high tone.

$$
\text { IWOYO (Mingas 1994:315-16) }
$$

a. Nàndí ùkótèzé kúnzò.

$$
\begin{array}{lll}
\text { nandi } & \text { u-Ø-kot-izi } & \text { ku-N-zo. } \\
\text { he } & \mathrm{SM}_{1} \text {-P1-enter-P1 } & \text { LOC }_{17}-\mathrm{NP}_{9} \text {-house }
\end{array}
$$

'He entered the house/He is inside the house.'

b. Nàndí ùkótézé kúnzò.

$$
\begin{array}{lll}
\text { nandi } & \mathrm{u}-\varnothing \text {-kot-izi } & \text { ku-N-zo. } \\
\text { he } & \mathrm{SM}_{1} \text {-P2-enter-P2 } & \mathrm{LOC}_{17}-\mathrm{NP}_{9} \text {-house }
\end{array}
$$

'He entered the house.'

The differentiation between the formally identical PRF/P2 and PRS/P3 by means of SMs (here $\mathrm{SM}_{1 \mathrm{SG}}$ ) is summarized in Table 6. Because we have neither robust tonal analyses in the sources nor enough data to make our own for most of these varieties, we cannot note tone, which is however the only feature distinguishing PRS from P3 in Kimbata, Kimbeko, Kintandu. Note that in Iwoyo there is no SM variation for

\begin{tabular}{|c|c|c|c|c|c|c|}
\hline & Variety & PRS & PRF & $\mathrm{P} 1$ & $\mathrm{P} 2$ & P3 \\
\hline West & $\begin{array}{l}\text { Iwoyo } \\
\text { Kiyombe }\end{array}$ & $\begin{array}{l}\text { i-i-B-a } \\
\text { ndi-N-B-a }\end{array}$ & $\begin{array}{l}\text { i-ma-B-a } \\
\text { N-Ø-B-idi }\end{array}$ & $\begin{array}{l}\text { i-Ø-B-izi } \\
\text { N-Ø-B-idingi }\end{array}$ & $\begin{array}{l}\text { i- } \emptyset-B-i z i \\
\text { ndi- } \emptyset-B-i d i\end{array}$ & $\begin{array}{l}\text { i- } \emptyset-B-a \\
\text { ndi- } \emptyset-B-a\end{array}$ \\
\hline East & $\begin{array}{l}\text { Kimbata, } \\
\text { Kimbeko, } \\
\text { Kintandu }\end{array}$ & i- $\emptyset-\mathbf{B}-\mathbf{a}$ & N-Ø-B-idi & N- $\varnothing$-B-idingi & i- $\emptyset$-B-idi & i- $\emptyset-B-a$ \\
\hline
\end{tabular}
the first person singular, and that the perfect is expressed by means of a prefix -ma-, which is discussed in section 3.1.6.

Table 6. Overview of combination 1SG subject markers and TA marker in varieties having lost the -a- prefix 


\subsection{2. -ta-B-a 'progressive'}

This TA marker expresses the present progressive and is attested in Kintandu, Kimbata, Kimbeko, Kizombo and Kinkanu, five varieties spoken in the eastern part of the KLC. Examples of Kinkanu and Kintandu are provided in (28) and (29).

KINKANU (KongoKing fieldwork 2012)

Mwana yakálá katánwa masá.

$\begin{array}{lll}\text { mu-anayakala } & \text { ka-ta-nu-a } & \text { ma-sa. } \\ \mathrm{NP}_{1} \text {-boy } & \mathrm{SM}_{1} \text {-PROG-drink-FV } & \mathrm{NP}_{6} \text {-water }\end{array}$

(29) KINTANDU (Daeleman 1966:261)

kisálú kyétó tútásála.

$\begin{array}{lll}\text { ki-salu } & \text { ki-eto } & \text { tu-ta-sal-a. } \\ \mathrm{NP}_{7} \text {-work } & \mathrm{PP}_{7} \text {-POSS } & \mathrm{SM}_{1 \mathrm{PL}} \text {-PROG-work-FV }\end{array}$

'We are doing our work/we are busy working.'

Mpanzu (1994:132-33) notes that Kizombo has two progressive constructions, viz. one with the -ta- marker (30) and one consisting of the 'be+locative+infinitive' construction. The -ta- progressive is not discussed in the Kizombo language course of Carter \& Makondekwa (1987), while the other construction is. However, the existence of the -ta- prefix in Kizombo has been confirmed by Afonso Teca (pers. comm.), an Angolan linguist and native speaker of this Kikongo variety.

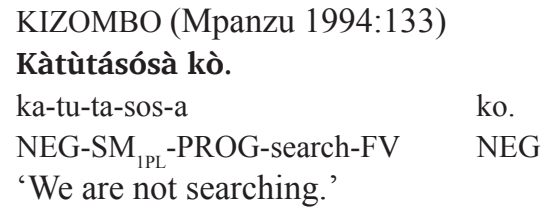

\subsection{3. kani/kana ... ko 'not yet'}

Comrie (1985:54) describes the 'not yet' tense as a combination of absolute tenses, expressing that "a certain situation (...) did not hold in the past and does not hold in the present, i.e. that it is still the case that a situation does not hold." While this concept tends to be lexically conveyed in many European languages, and especially by adverbs such as 'not yet' in English, it is commonly grammaticalized in Bantu (Nurse 2008:196-200). The 'not yet' marker is a special negative marker in that it lacks an affirmative equivalent (Nurse 2008:200). This tense has the same distribution as the progressive marker -ta-. It is found in Kintandu, Kimbata, Kimbeko, Kizombo and Kinkanu, where it is expressed via the auxiliary kani (or kana in Kizombo), which is the negative form of the defective verb -na 'be', taking the negative $\mathrm{SM}_{1}$ ka- and the negative FV -i. A Kimbata example is provided in (31). 


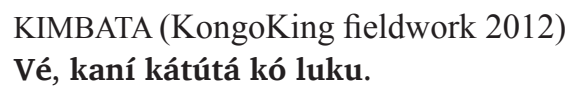

\subsection{4. -eka- 'inceptive, near future'}

The formative -eka- is attested in a number of varieties located in the western part of the KLC, namely Kisundi, Kiyombe, Iwoyo, Ciwoyo and Cizali. Semantically, it expresses inception or near future, as shown in the Kisundi example (32). Nurse (2008:161) considers the inceptive as a 'minor' TA category in Bantu.

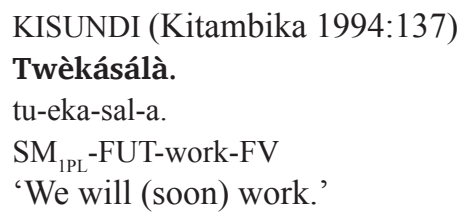

The combination with other TA markers can impact the meaning of the inceptive marker in Kikongo. For example, when -eka- is followed by the present marker -Nin Kiyombe, it has a present progressive meaning (33). However, if there is no overt TA marker, -eka- expresses its basic inceptive meaning (34).

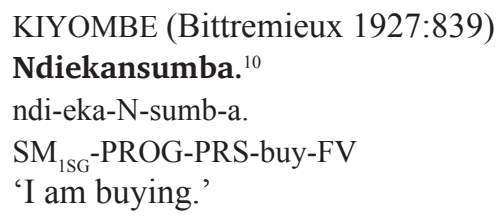

10. One reviewer pointed out that there are three similar progressive forms in Kiyombe, viz. i) the fronted-infinitive construction in combination with the formative - $\mathbf{N}$ - in the second, finite verb (sumba ndinsumba 'I am buying'), ii) the finite verb from the previous construction only (ndinsumba 'I buy/am buying'), and iii) the -eka- prefix as in example (33). Although no clarification is given in De Clercq (1921) on the differences between these three apparent similar forms, our impression is that the fronted-infinitive construction is still closely linked to pragmatics, since it functions as a predicate-centered focus device (De Kind et al. 2015). The form with the homorganic nasal prefix was a dedicated progressive marker which has undergone semantic broadening to express also imperfectivity, although solely in present tense. Moreover, it evolved from what was originally a progressive marker, viz. the mu INF construction (see section 1.6.). Finally, there is a strong correlation between a progressive event, which is ongoing and thus not yet completed, and the inceptive, which indicates that the event is about to happen. It is certain that the translations provided in the source do not capture the nuances of the differences between these three forms. 
In the B40 languages Isangu and Yipunu, similar prefixes involving the consonant $/ \mathbf{k} /$, but with different vowels, are attested expressing 'imminent' or 'near' future. These forms are shown in (35) and (36).

ISANGU (Ondo-Mebiame 2000:203)

\section{Ìkòtsítsó múnéndyítsì.}

i-ka-tsits-a mu-nendyitsi.

$\mathrm{SM}_{2 \mathrm{SG}}$-FUT-call-FV $\mathrm{NP}_{1}$-teacher

'You are going to call the teacher.'

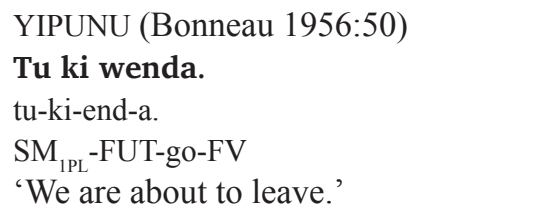

\subsubsection{Future paradigm}

The western varieties Kiyombe, Iwoyo, Ciwoyo and Cizali make a temporal distinction for future time reference not found in the other Kikongo varieties, and have the same formal means to express near future (F1), viz. the auxiliary -kwiza 'come', and remote future (F2), viz. the TA prefix -ala-/-ela-.

Verbs denoting the motion event 'come' often grammaticalize into future tense markers (Botne 2006, Bybee et al. 1994:267-70). Although the development of 'come' verbs into future markers occurs throughout Bantu, variation in semantic evolution, stage of grammaticalization and the scattered distribution indicates that these are unrelated, individual innovations (Nurse 2008:85). It is not atypical that 'come' verbs develop specifically into near future markers (Bybee et al. 1994:271-73, Nurse 2008:85), although this is not universally so (Botne 2006). The near future construction in Cizali with -kwiza is illustrated in (37).

CIZALI (KongoKing fieldwork 2012)
$\begin{array}{lll}\text { Náánga kikwíza nóki ko. } & & \\ \text { naanga ki-kwiz-a } & \text { nok-i } & \text { ko. } \\ \begin{array}{l}\text { perhaps NEG.SM } \\ \text { 'Perhaps it won't rain.' }\end{array} & & \text { rain-NEG.FVe-FV } \\ \end{array}$

Interestingly, Nurse (2008:85) states that "derivatives of the verb 'come' [...] occur [...] locally all across Bantu [...], outside of the northwest" (emphasis our own). ${ }^{11}$ The data presented here indicates, on the contrary, that at least some of what Nurse considers to be northwestern Bantu languages, i.e. the western Kikongo varieties, do have this grammaticalized strategy.

11. Nurse (2008:10) specifies that various authors have included different languages in the northwest group, with the core group mainly consisting of the languages of zone A and B. He continues that "[e]xactly which languages an author includes under this label often depends on what the author has in mind" (Nurse 2008:10). His map of northwestern Bantu clearly includes the H10 Kikongo group (Nurse 2008:6). 
The second future marker is a combination of the remote TA prefix -a- and the common Bantu future marker -la- (Nurse 2008:85, Nurse \& Philippson 2006:175-76), which has been proposed to go back to Proto-Bantu and has been reconstructed with a long vowel *-laa- (Nurse 2008:253, Nurse \& Philippson 2006:75). In grammars of western Kikongo varieties, such as Iwoyo in (38), it is described as a remote future marker (F2).

$$
\begin{aligned}
& \text { IWOYO (Mingas 1994:321) } \\
& \text { Mìnú ìálálíyá mákùndì. } \\
& \text { minu i-ala-li-a ma-kundi. } \\
& \text { I } \quad \mathrm{SM}_{1 \mathrm{SG}} \text {-F2-eat-FV } \quad \mathrm{NP}_{6} \text {-fruit } \\
& \text { 'I will eat fruit.' }
\end{aligned}
$$

Synchronically, the remote prefix and the reflex of the historical future marker -laneed to be analyzed as a single marker, since -la- is not used by itself to denote any type of future time reference. It is only found as part of -ala- or as its variant -ela- (39).

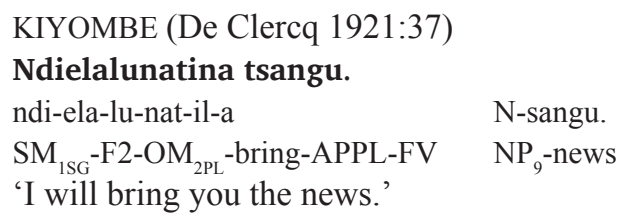

Cizali is exceptional here in that it shares the innovative future markers with Kiyombe, Iwoyo and Ciwoyo, but also has retained the more widespread future marker si, as shown in (40).

(40) CIZALI (KongoKing fieldwork 2012)

a. Búúbu, si yávunda.

$$
\begin{aligned}
& \text { buubu si i-a-vund-a. } \\
& \text { today FUT } \mathrm{SM}_{1 \mathrm{SG}} \text {-REM-rest-FV } \\
& \text { 'Today, I will rest.' }
\end{aligned}
$$

b. Másíka mááma, kukwíza kángi ko umwelo.

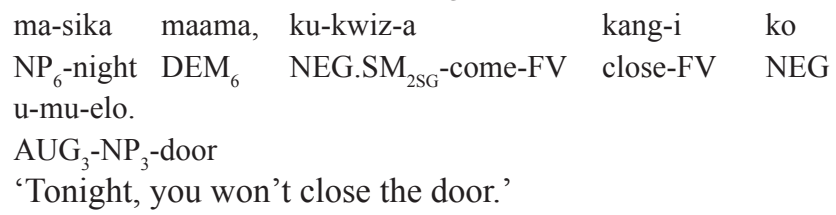

c. Bána ba nduumba babwáli beladengana ku sikuulu.

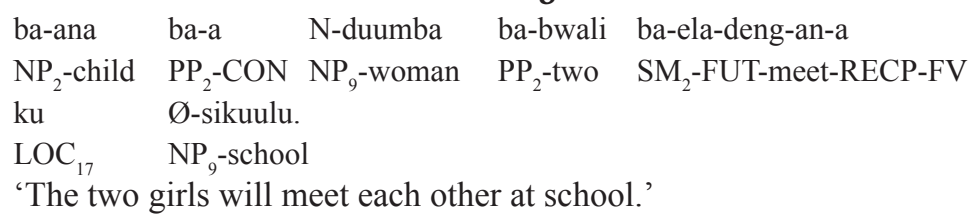

The semantic particularities distinguishing the three future tense markers, -kwiza, -ela- and si, will be the subject of future research. 


\subsubsection{Prefix -m(w)a-/-me- 'perfect'}

A number of similar forms are found in the western varieties Kiyombe, Iwoyo and Ciwoyo, in the north-western B40 languages Isangu, Yilumbu and Yipunu, and in the northern variety Kibembe. In all these varieties, the meaning of the formative centers around the perfect. The different forms -me-, -ma- and -mwa- are illustrated in the examples (41) to (43).

(41) KIYOMBE (Bittremieux 1927:839)

\section{Tumesumba.}

tu-me-sumb-a.

$\mathrm{SM}_{1 \mathrm{PL}}$-PRF-buy-FV

'I have (already) bought.'

(42) CIWOYO (KongoKing fieldwork 2012)

Nkhyóngá mazêngá nsóso.

$\begin{array}{lll}\mathrm{N} \text {-konga } \quad \varnothing \text {-ma-zeng-a } & \mathrm{N} \text {-soso. } \\ \mathrm{NP}_{9} \text {-hunter } \quad \mathrm{SM}_{1} \text {-PRF-cut-FV } & \mathrm{NP}_{9} \text {-tail } \\ \text { 'The hunter has cut the tail.' } & \end{array}$

\footnotetext{
KIBEMBE (Kouarata 2015:108)

Nyóko yimwáakóto.

N-nyoko i-mwaa-kot-o.

$\mathrm{NP}_{9}$-snake $\mathrm{SM}_{9}$-PRF-enter-FV

'The snake has already entered.'
}

This marker is grammaticalized from the verb -mana 'finish', which is still attested in its full form as a perfect construction in Kimanyanga as described by Laman (1912) (44a). Functioning as an auxiliary, the verb is found outside of the western region of the KLC and can furthermore be inflected for the perfect resulting in the imbricated form -meni 'have finished' (44b). This could well be the source of grammaticalization for -me- as found in Kiyombe (41).

(44) KIMANYANGA (Laman 1912:163)

a. Imana kanga.

i-Ø-man-a Ø-kang-a.

$\mathrm{SM}_{1 \mathrm{SG}}$-PRS-finish-FV $\quad \mathrm{NP}_{15}$-catch-FV

'I have caught.'

b. Mbeni kanga. ${ }^{12}$

N-Ø-man-idi Ø-kang-a.

$\mathrm{SM}_{1 \mathrm{SG}}$-PRS-finish-PRF $\quad \mathrm{NP}_{15}$-catch-FV

'I had caught.'

12. The creation of NC clusters is regular in Kikongo when a nasal-initial stem is preceded by a non-syllabic prefix of classes 9/10 or 1sg (Laman \& Meinhof 1928-29:27). Herbert (1986:227) argues that this dissimilation rule is formally the reverse of Meinhof's Law or Rule (Meeussen 1962). This is indeed the case, except that in the case of Meinhof's Rule, a $\mathrm{NC}$ cluster is only reduced to $(\mathrm{N}) \mathrm{N}$ when it is followed by another $\mathrm{NC}$ cluster or a simple nasal. In Kikongo, an NN sequence can also be turned into NC when no nasal (complex) follows in the next syllable, as shown in (44b) and the first example in Table 5. 
The development of perfect markers from the verb 'finish' is cross-linguistically common (Bybee et al. 1994:56, 58). Within Bantu, the use of -mana 'finish' is a common strategy to express completive aspect. Moreover, according to Nurse (2008:125, 252-53), most Bantu languages that have a perfect marker of the shape -ma-, -me- or -mwaa- belong to northwestern Bantu, suggesting "a single common historical innovation" (ibid.:253). However, within the KLC, this innovation seems to be characteristic of the western varieties and cannot be reconstructed to Proto-Kikongo. It is only in Ciwoyo, Iwoyo, Kiyombe and Kibembe that the auxiliary has grammaticalized into a dedicated perfect formative. In these varieties the function of -ma-/-me- has narrowed to marking perfect only, whereas in present-day Kimanyanga, for instance, the auxiliary can still be inflected with perfect (45a) or past (45b), resulting in readings different than only perfect.

KIMANYANGA (Makokila Nanzanza 2012:190-93)

a. Bamweni futá.

ba-Ø-man-idi $\varnothing$-fut-a.

$\mathrm{SM}_{2}$-PRS-finish-PRF $\quad \mathrm{NP}_{15}$-pay-FV

'They have paid.'

b. Twamwení móvela.

tu-a-man-idi $\quad$-mo-vel-a.

$\mathrm{SM}_{1 \mathrm{PL}}$-P2-finish-P2 $\mathrm{NP}_{15}$-OM $\mathrm{OM}_{6}$-pluck-FV

'We have finished plucking them.'

As can be seen in (45), the surface form of the auxiliary in present-day Kimanyanga is -mweni. Although imbrication can account for the surface form -meni attested in Laman (1912), the phonological process(es) possibly underlying the glide formation of -mweni are not explained in Makokila (2012).

This innovation is not restricted to the western Kikongo varieties but also occurs in some B40 languages located further to the north. As is shown in (46), a perfect marker with the form -ma- is found in Isangu (B42) and Yipunu (B43). Note that in Yipunu the formative does not denote the perfect, but has a past completive meaning. Bonneau $(1956: 51,57)$ gives as "parfait immédiat" the form SM-ba no-B-a, e.g. ni ba no sala 'I have (just) worked'.

(46) a. ISANGU (Ondo-Mebiame 2000:202)

\section{Bâ: nò bə̀móvyòsò.}

ba-ana ba-ma-vyos-a.

$\mathrm{NP}_{2}$-child $\mathrm{SM}_{2}$-PRF-pass-FV

'The children have (just) passed.'

b. YIPUNU (Bonneau 1956:58)

Umasinga.

u-ma-sing-a.

$\mathrm{SM}_{2 \mathrm{SG}}$-PST-believe-FV

'I believed.' 


\subsubsection{Spirantized reflex -izi}

Some Kikongo varieties have a spirantized reflex of the Proto-Bantu final *-ide, as shown in (47) for Ciwoyo. Its distribution is confined to the west of the KLC, as it was only found in Cizali, Iwoyo, Ciwoyo and Civili.

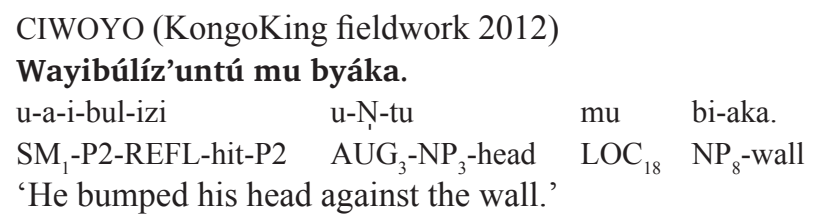

Bantu spirantization is commonly triggered by the Proto-Bantu closed front and back vowels *i and *u (Bostoen 2008, Schadeberg 1995). As summarized in (48), the raising of the suffix's final vowel, due to harmony with its first vowel, subsequently led to the spirantization of the suffix's consonant in most western Kikongo varieties (Bastin 1983:42).

$$
\text { *-ide } \rightarrow \text {-idi } \rightarrow \text {-izi }
$$

The intermediate stage is still attested in non-western Kikongo varieties and in Kiyombe (49).

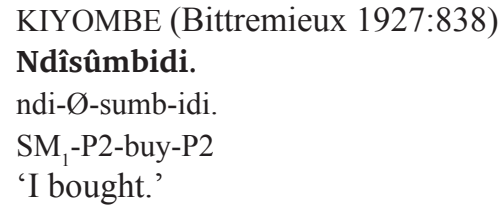

Bastin (1983:42) reports that the western variety Civili also has a spirantized final, which has undergone an additional devoicing resulting in -isi (50).

$$
\begin{aligned}
& \text { CIVILI (Bastin 1983:42) } \\
& \text {-tola 'be strong' } \rightarrow \\
& \text {-bula 'fight' } \quad \rightarrow \quad \text {-tolisi } \\
& \text {-bulisi }
\end{aligned}
$$

\subsubsection{Shift in past tense paradigm}

In section 3.1.6. it has been shown that the category of the perfect is expressed by the TA prefix -ma-/-me- in the western Kikongo varieties Iwoyo, Ciwoyo and Kiyombe, rather than by the common TA marker - $\emptyset$-B-idi. This has resulted in a semantic reshuffling of past forms and meanings in these varieties, where the common perfect marker $-\varnothing$-B-idi has the meaning (hodiernal) past (P1) instead of present perfect (51).

13. No translation is given in Bastin (1983) for the perfect forms. 

CIWOYO (KongoKing fieldwork 2012)
Mwána ngómbó bútukwizi myena.
mu-ana N-gombo Ø-Ø-butuk-izi myena.
$\mathrm{NP}_{1}$-child $\quad \mathrm{NP}_{9}$-cow $\mathrm{SM}_{1}$-P1-be.born-P1 morning
'A calf was born this morning.'

This reshaping of the past tense paradigm has resulted in the absence of the complex final -izingi in Iwoyo and Ciwoyo. In the western part of the KLC, this final is still found in Cizali (52) and Kiyombe (53).

CIZALI (KongoKing fieldwork 2012)

Kizizíngi nthángu mfúmu ka yikwénda.

$\begin{array}{lllll}\text { ka- } \varnothing \text {-iz-izingi } & \mathrm{N} \text {-tangu } & \mathrm{N} \text {-fumu } & \mathrm{ka} & \mathrm{i} \text { - } \varnothing \text {-kwend-a. } \\ \mathrm{SM}_{1} \text {-P1-come-P1 } & \mathrm{NP}_{9} \text {-time } & \mathrm{NP}_{9} \text {-chief } & \text { PRED } & \mathrm{SM}_{9} \text {-PRS-go-FV } \\ \text { 'He arrived just when the chief was leaving.' }\end{array}$

(53) KIYOMBE (De Clercq 1921:41)

ndivénenge.

ndi-Ø-van-idingi.

$\mathrm{SM}_{1 \mathrm{SG}}-\mathrm{P} 1$-give-P1

'I gave.'

Kiyombe, as described by De Clercq (1921), seems to have a combination of conservative and innovative features. The perfect has two competing forms, -me-B-a ("parfait présent"; De Clercq 1921:37) and -Ø-B-idi ("parfait présent"), both with a homorganic nasal as $\mathrm{SM}_{1 \mathrm{SG}}$. P1 ("parfait très éloigné") is expressed by the Proto-Kikongo final -idingi as well as - $\emptyset$-B-idi. The latter is distinguished from the morphologically identical perfect marker in that it takes the $\mathrm{SM}_{1 \mathrm{SG}}$ ndiand the verb stem has a high tone (ibid.). Finally, due to the loss of the -a- prefix, P2 ("parfait très éloigné") is also marked by - $\varnothing-\mathrm{B}-\mathbf{i d i}$ with a high stem. P1 and P2 are distinguished by different tones on the SMs: in P1 the $\mathrm{SM}_{1 \mathrm{SG}}$ is low, ndì-, and $\mathrm{SM}_{1 \mathrm{PL}}$ is high, tú-, whereas in $\mathrm{P} 2$ the opposite holds (these are the only two persons given in De Clercq 1921:37). An overview of this complex situation is provided in TabKiyaka (H31) (Van Den Eynde 1968)low. ${ }^{14}$

As discussed in section 3.1.1., due to the loss of the -a- prefix in Iwoyo, the circumfix - $\varnothing$-B-idi expresses both P1 (54a) and P2 (54b), although tonally differentiated. In Ciwoyo (55) and Cizali (56), P2 is expressed by the common Kikongo marker -a-B-izi.

$$
\text { IWOYO (Mingas 1994:311, 316) }
$$

a. Nàndí ùlílìzí.

$$
\begin{aligned}
& \text { nandi u- } \varnothing \text {-lil-izi. } \\
& \text { he SM }- \text {-P1-cry-P1 } \\
& \text { 'He cried.' }
\end{aligned}
$$

14. Still more forms are given in De Clercq (1921), such as SM-fuma-B-i (tufumasumbi 'I have just bought'), or the formally identical but tonally different parfait passé SM- $\emptyset-B-a$ (ndisúmba 'I bought') and parfait très éloigné SM-Ø-B-a (ndísúmba 'I bought'). 
b. Nàndí ùwéndézé kú nsítù.

nandi $\mathrm{u}$-Ø-end-izi $\mathrm{ku} \quad \mathrm{N}$-situ.

he $\quad \mathrm{SM}_{1}$-P2-go-P2 LOC $_{17} \quad \mathrm{NP}_{9}$-forest

'He went to the forest.'

(55) CIWOYO (KongoKing fieldwork 2012)

Káyizízi yono ko.

ka-a-iz-izi yono ko.

NEG.SM - P2-come-P2 yesterday NEG

'He did not come yesterday.'

(56) CIZALI (KongoKing fieldwork 2012)

Watuutiz'umáánya yónwe?

u-a-tuut-izi u-ma-anya yono e?

$\mathrm{SM}_{2 \mathrm{SG}}-\mathrm{P} 2$-pound-P2 $\mathrm{AUG}_{6}-\mathrm{NP}_{6}$-corn yesterday $\mathrm{Q}$

'Did you pound the corn yesterday?'

Table 7. Overview of some past tenses in Kiyombe as described by De Clercq (1921:36-37)

\begin{tabular}{|c|c|c|c|}
\hline Meaning & Form & Example & \\
\hline \multirow[t]{2}{*}{ PRF } & SM-me-B-a & $\begin{array}{l}\text { Mbesumba. } \\
\text { N-me-sumb-a. } \\
\text { SM }_{1 \mathrm{SG}} \text {-PRF-buy-FV } \\
\text { 'I have already bought.' }\end{array}$ & $\begin{array}{l}\text { Tumesumba. } \\
\text { tu-me-sumb-a. } \\
\mathrm{SM}_{1 \mathrm{PL}}-\mathrm{PRF}-\mathrm{buy}-\mathrm{FV} \\
\text { ' 'We have already bought.' }\end{array}$ \\
\hline & SM- $\emptyset$-B-idi & $\begin{array}{l}\text { Tsumbidi. } \\
\text { N-Ø-sumb-idi } \\
\text { SM }_{1 \mathrm{SG}} \text {-PRS-buy-PRF } \\
\text { 'I have bought.' }\end{array}$ & $\begin{array}{l}\text { Tusumbidi. } \\
\text { tu- } Ø \text {-sumb-idi. } \\
\mathrm{SM}_{1 \mathrm{PL}}-\mathrm{PRS}-\text { buy-PRF } \\
\text { 'We have bought.' }\end{array}$ \\
\hline \multirow[t]{2}{*}{ P1 } & SM- $\varnothing$-B́-idingi & $\begin{array}{l}\text { Ndisúmbidingi. } \\
\text { ndi-Ø-sumb-idingi. } \\
\mathrm{SM}_{1 \mathrm{SG}}-\mathrm{P} 1-\text { buy-P1 } \\
\text { 'I bought.' }\end{array}$ & $\begin{array}{l}\text { Tusúmbidingi. } \\
\text { tu-Ø-sumb-idingi. } \\
\mathrm{SM}_{1 \mathrm{PL}}-\mathrm{P} 1-\text { buy-P1 } \\
\text { 'We bought.' }\end{array}$ \\
\hline & SM- $\varnothing-B ́-i d i$ & $\begin{array}{l}\text { Ndísúmbídi. } \\
\text { ndi-Ø-sumb-idi. } \\
\text { SM }_{1 \mathrm{SG}} \text {-P1-buy-P1. } \\
\text { 'I bought.' }\end{array}$ & $\begin{array}{l}\text { Tusúmbidi. } \\
\text { tu-Ø-sumb-idi. } \\
\text { SM }_{1 \mathrm{PL}}-\mathrm{P} 1-\text { buy-P1 } \\
\text { 'We bought.' }\end{array}$ \\
\hline P2 & SM-Ø-B́-idi & $\begin{array}{l}\text { Ndísúmbidi. } \\
\text { Ndi-Ø-sumb-idi. } \\
\text { SM }_{1 \mathrm{SG}} \text {-P2-buy-P2 } \\
\text { 'I bought.' }\end{array}$ & $\begin{array}{l}\text { Túsúmbídi. } \\
\text { tu-Ø-sumb-idi. } \\
\mathrm{SM}_{1 \mathrm{PL}}-\mathrm{P} 1-\text {-buy-P1 } \\
\text { 'We bought.' }\end{array}$ \\
\hline
\end{tabular}


As a summary, the past tense paradigms for each western variety are given in Table 8 . The hypothetical Proto-Kikongo (PK) forms are first given as a reference point to facilitate the presentation of the various changes. Each innovation is marked by a different contour: -a- loss in green, -ma-/-me- perfect marker in purple and the shift of PK *- $\emptyset$-B-idi from present perfect to hodiernal past in blue. The spirantization of -idi is indicated by an orange shade.

Table 8. Past tense paradigms of some western varieties

\begin{tabular}{|c|c|c|c|c|c|}
\hline Function & PK & CIZALI & CIWOYO & IWOYO & KIYOMBE \\
\hline \multirow[t]{2}{*}{ PRF } & & & -ma-B-a & -ma-B-a & -ma-/-me-B-a \\
\hline & ${ }^{*}$-Ø-B-idi & -Ø-B-izi & & & -Ø-B-idi \\
\hline \multirow[t]{2}{*}{$\mathrm{P} 1$} & & & -Ø-B-izi & -Ø-B-izi & -Ø-B́-idi \\
\hline & $*-\emptyset$-B-idingi & -Ø-B-izingi & & & - $\emptyset$-B-idingi \\
\hline $\mathrm{P} 2$ & $*$-a-B-idi & -a-B-izi & -a-B-izi & -Ø-B-izi & -Ø-B-idi \\
\hline P3 & $*$-a-B-a & -a-B-a & -a-B-a & $-\varnothing-B-a$ & -Ø-B-a \\
\hline
\end{tabular}

\subsection{9. -eta-/-eti-'present'}

The formative -eta-/-eti- is attested in a number of varieties of the central and western part of the KLC: Kimanyanga, Kimboma, Kiyombe, Kisundi and Ciwoyo. As is shown in (57), it expresses varying aspectual meanings such as progressivity in Kimboma (57a), habituality in Kiyombe (57b), or generic present in Ciwoyo (57c).

(57) a. KIMBOMA (Kisilu Meso 2001:44)

Twetivova.

tu-eti-vov-a.

$\mathrm{SM}_{1 \mathrm{PL}}$-PR.PROG-talk-FV

'We are talking.'

b. KIYOMBE (De Clercq 1921:37)

Twetasumba.

tu-eta-sumb-a.

$\mathrm{SM}_{1 \mathrm{PL}}$-PRS.HAB-buy-FV

'We (often) buy.'

c. CIWOYO (KongoKing fieldwork 2012)

Báwóyo, bétilyá mbyómá?

ba-woyo ba-eti-li-a N-boma?

$\mathrm{NP}_{2}$-Woyo $\mathrm{SM}_{2}$-PRS-eat-FV $\quad \mathrm{NP}_{9}$-python

'Do the Woyo people eat python?' 
Regarding the form of the prefix, both -eta- and -eti- are attested. Whereas the latter could be analyzed as a contraction of -eta- and the present marker -i- in Ciwoyo, this does not hold for Kisundi, Kimanyanga and Kimboma, which do not have the -i- formative. Moreover, the currently known distribution of -eta- is restricted to Kiyombe only, in contrast to -eti-, which is found in Ciwoyo, Kisundi, Kimanyanga and Kimboma. More research is required to investigate the origin and morpho-phonological changes of this prefix.

\subsubsection{0. -i- 'present'}

This TA marker is a very local innovation attested in the two neighboring varieties Ciwoyo and Iwoyo. The formative functions as a present tense marker (58a). Progressive aspect is expressed by means of a fronted infinitive construction involving the infinitive and the finite verb inflected with the present tense -i-, as in (58b). Fronted infinitive constructions are a frequently used strategy for progressive aspect in Kikongo (De Kind et al. 2015) as well as in Bantu more generally (Güldemann 2003, Hadermann 1996).

$$
\text { IWOYO (Mingas 1994:311) }
$$

a. Nàndí ùílílà.

nandi u-i-lil-a.

he $\quad \mathrm{SM}_{1}$-PRS-cry-FV

'He cries.'

b. Nàndí kúná kíkúnà mádèzò.

$\begin{array}{lll}\text { nandi } \varnothing \text {-kun-a } & \text { ka-i-kun-a } & \text { ma-dezo. } \\ \text { he } \mathrm{NP}_{15} \text {-plant-FV } \quad \mathrm{SM}_{1} \text {-PRS-plant-FV } & \mathrm{NP}_{6} \text {-bean } \\ \text { 'He is planting the beans.' } & \end{array}$

Nsayi $(1984: 261,271)$ states that Kibembe, a variety of the RC located in the northern part of the KLC, also has -i- as one of many present tense marker(s), but does not provide any examples.

A similar present tense marker is described for Yipunu in Bonneau (1956:54). It involves the formative -i-, but differs from the marker in Iwoyo and Ciwoyo in that it has a final vowel -i, as shown in (59), rather than -a.

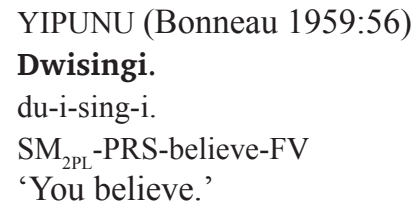

Such a final vowel is also found e.g. in Lingála as a reflex of *-ide (Brisard \& Meeuwis 2009). One could wonder whether final -i in Yipunu is therefore related to the Proto-Bantu *-ide suffix. A change from perfect — which is the common function of -idi in most present-day Kikongo varieties in combination with an empty TA-slot - to present is not a far-fetched semantic stretch. However, no such claims have been made in the literature and therefore we do not elaborate this possible historical scenario, which should be taken up in future research. 


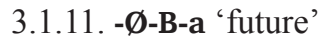

As discussed in section 1.4., this 'null' form is the most common present tense marker throughout Bantu, and also in Kikongo. The varieties in which this form denotes future time reference are Kisolongo, Kisikongo and Kizombo, all spoken in the southern part of the KLC located in Angola, and Kibembe, a northern variety in Congo-Brazzaville.

Present tense markers obtaining additional future meaning or becoming specialized future markers is a development observed elsewhere in Bantu (Nurse 2008:118) and in the world's languages (Haspelmath 1998). The temporal frame defining the 'present' is not restricted to the moment of speech, but is rather a deictic domain in which the speaker places himself and the event marked for the present tense. It is a time unit that is relevant, real and contemporal for the speaker (Botne \& Kershner 2008:159) and stretches out beyond the narrow utterance time both into the past and the future. Thus, in the meaning of the present already resides an immediate future sense, which lies at the heart of the semantic shift from present to future. This can be observed in the eastern Kikongo variety Kinkanu in (60), where the basic meaning of the null form is present tense (60a) but it can also be used to refer to events in the near future (60b).

(60) KINKANU (KongoKing fieldwork 2012)

a. Nkhátu, kayidyá ko madyoku.

nkhatu, ka-i-Ø-di-a ko ma-dyoku.

no $\quad \mathrm{NEG}-\mathrm{SM}_{1 \mathrm{SG}}$-PRS-eat-FV NEG $\mathrm{NP}_{6}$-cassava

'No, I don't eat cassava.'

b. Nkhí yílamba?

nkhi i-Ø-lamb-a?

what $\mathrm{SM}_{1 \mathrm{SG}}$-PRS-cook-FV

'What shall I cook?'

As Haspelmath $(1998: 30,33)$ points out, this development is interesting in that 1) more often than not future tense is more marked (formally) than present, which in this situation is the opposite, resulting in a markedness violation (Haspelmath 1998:45), and 2) this is not a case of grammaticalization, which is one of the main mechanisms behind the development of new TA markers (cf. Bybee et al. 1994). Examples of this 'zero' future in southern Kikongo varieties are shown in examples (61) to (63), and in (64) for Kibembe. In the southern Kikongo languages, a number of forms, such as - $\varnothing$-B-idi with stative verbs $(61 \mathrm{~b})$, the fronted infinitive construction (62b), mu INF or - $\emptyset$-B-ang-a (63b) with dynamic verbs, are used to express present tense (logically, each with a different aspectual meaning).

(61) KISOLONGO (KongoKing fieldwork 2012)

a. Okwíza kwándi mbázye?

$\begin{array}{llll}\text { o-Ø-kwiz-a } & \text { ku-andi } & \text { mbazi } & \text { e? } \\ \text { SM }- \text {-FUT-come-FV } & \text { PP }_{17}-P_{1} S_{1} & \text { tomorrow } & \text { Q } \\ \text { 'Will he come tomorrow?' } & & \end{array}$


b. Pé, ketulééle ko.

pe, ke-tu-Ø-laal-idi ko.

no NEG-SM 1 PL - PRS-sleep-PRF NEG

'No, we are not asleep.'

(62) KISIKONGO (a: Ndonga Mfuwa 1995:359; b: De Kind et al. 2015)

a. Kyà lúmíngù n'túngà énzò.

ki-a lumingu N-Ø-tung-a e-N-zo.

$\mathrm{PP}_{7}$-CON Sunday $\quad \mathrm{SM}_{1 \mathrm{SG}}$-FUT-build-FV $\quad \mathrm{AUG}_{9}-\mathrm{NP}_{9}$-house

'I will build the house on Sunday.'

b. Kadi samba kesamba.

kadi Ø-samb-a ke-Ø-samb-a.

but $\quad \mathrm{NP}_{15}$-pray-FV $\mathrm{SM}_{1}$-PRS-pray-FV

'But he is praying.'

(63) KIZOMBO (Carter \& Makondekwa 1987:106, 23)

a. Avǒ kìlamba ko, kìdya ko.

avo ki-Ø-lamb-a ko, ki-Ø-di-a ko.

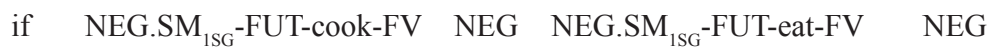

'If I don't cook, I won't eat.'

b. Nkhǐ kávvaangaangá? Mùddya kén'ee?

nkhi ka-Ø-vang-ang-a? mu-di-a ${ }^{15}$ ka-in-a e?

Q $\quad \mathrm{SM}_{1}$-PRS-do-PROG-FV $\quad \mathrm{NP}_{18}$-eat-FV $\quad \mathrm{SM}_{1}$-be-FV Q

'What is s/he doing? Is s/he eating?'

(64) KIBEMBE (Kouarata 2015:100)

Bó basála.

bo ba-Ø-sal-a.

they $\quad \mathrm{SM}_{2}$-FUT-work-FV

'They will work.'

Although Kouarata (2015) does not discuss the matter, a comparison of the present and future tense examples, both having the - $\varnothing$-B-a inflection, shows no difference in the tonal pattern. In both tense forms the root takes a high tone, and the SM and FV are low.

\subsubsection{2. -ku- 'future'}

The most southern varieties Dihungu and Kitsootso do not share the zero future, but denote future tense by means of the TA prefix -ku-, as shown in (65b) and (66b). In Kitsootso, the 'null' form has maintained its present meaning (65a). In Dihungu the present is expressed by the circumfix -a-B-a (66a). As shown in 2.1., Kitsootso also has a generic present marker with the form -a-B-a.

15. We have retained the affixal analysis of $\mathrm{NP}_{18} \mathbf{m u}$ - as it is written in the original source. In doing so, we remain neutral as to whether this analysis is correct, or whether the NP should be analyzed as a separated, preverbal element. 
(65) KITSOOTSO (Baka 1992:105, 106)

a. Ǒ áthu atuzola.

o-a-thu a-Ø-tu-zol-a.

$\mathrm{AUG}_{2}-\mathrm{NP}_{2}$-person $\quad \mathrm{SM}_{2}-\mathrm{PRS}-\mathrm{OM}_{1 \mathrm{PL}}$-love-FV

'Those people love us.'

b. Lwá lúlumí kákúzénga.

lwa lu-limi ka-ku-zeng-a.

$\mathrm{DEM}_{11} \quad \mathrm{NP}_{11}$-tongue $\quad \mathrm{SM}_{1}$-FUT-cut-FV

'He is going to cut that tongue.'

(66) DIHUNGU (Atkins 1955:154)

a. Twasumba.

tu-a-sumb-a.

$\mathrm{SM}_{1 \mathrm{PL}}$-PRS-buy-FV

'We buy.'

b. Tukusumba.

tu-ku-sumb-a.

$\mathrm{SM}_{1 \mathrm{PL}}$-FUT-buy-FV

'We shall buy.'

\subsubsection{3. -tsi- 'past' or 'perfect'}

This TA prefix, attested in Isangu as -tsa- (Ondo-Mebiame 2000:202) or -tsə(Idiata 2006:50), and in Yipunu and Yilumbu as -tsi- (Bonneau 1956:50, Gamille 2013:247) is restricted to the B40 languages considered in our sample. As can be seen from the examples in (67) to (69), it functions as a perfect or past formative.

(67) ISANGU (Idiata 2007:50)

Mwanə atsəbula paambə.

mu-ana a-tsə-bul-a paambə.

$\mathrm{NP}_{1}$-child $\mathrm{SM}_{1}$-PRF-break-FV bottle

'The child has broken the bottle.'

(68) YIPUNU (Bonneau 1956:50)

Mombu a tsi dji.

Mombu a-tsi-dji.

Mombu SM, - PRF-eat

'Mombu has eaten.'

(69) YILUMBU (Gamille 2013:247)

mùyátsy'âmì, àtsòbúr yò: nu

mu-yatsi ami a-tsi-bur-a yonu.

$\mathrm{NP}_{1}$-wife $\quad \mathrm{POSS}_{1 \mathrm{SG}} \quad \mathrm{SM}_{1}$-PST-give.birth-FV yesterday

'My wife gave birth yesterday.' 


\subsubsection{4. -(a)ko- 'generic present, 'habitual'}

Both Kibembe and Kikamba, two neighboring Kikongo varieties of the RC, share a formative -(a)ko-, which denotes generic or habitual aspect (70)-(71).

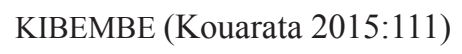

(71) KIKAMBA (Bouka 1989: no page numbers)

\section{Nàkósàlá.}

n-ako-sal-a.

$\mathrm{SM}_{1 \mathrm{SG}}$-HAB-work-FV

'I work.'

\subsection{TA innovations and the internal classification of the KLC}

In the previous subsection we presented an overview of changes in the TA system that took place posterior to Proto-Kikongo. In this section, we assess whether these are shared innovations indicative of genealogical subgrouping within the KLC or whether they are rather to be considered as independent and/or contact-induced innovations.

\subsubsection{East Kikongo}

Two TA constructions demarcate an eastern subgroup consisting of Kintandu, Kimbata, Kimbeko, Kinkanu and Kizombo, i.e. the progressive formative -ta(cf. 3.1.2.) and the 'not yet' construction kani/kana ... ko (cf. 3.1.3.). The loss of the TA prefix -a- (cf. 3.1.1.) is an in-group innovation shared only by Kintandu, Kimbata and Kimbeko. This loss is also observed in the western Kikongo varieties Kiyombe and Iwoyo, although this is most likely an independent innovation. We thus observe an eastern 'core' cluster consisting of Kintandu, Kimbata and Kimbeko, which share a set of three innovations, and an eastern periphery consisting of Kinkanu and Kizombo, which only share two of these innovations. These eastern varieties, except Kizombo, also constitute a discrete subgroup in the phylogenetic study of de Schryver et al. (this volume). Kizombo is phylogenetically classified as part of South Kikongo, but in close contact with East Kikongo, especially with Kimbata, which is spoken in the same Congolese sector of Mfidi Malele (Ntunda Nzeza 2007:59-61). The presence of the progressive -ta- and the 'not yet' construction kani/kana ... ko in Kizombo is thus possibly a contact-induced influence from Kimbata. An overview is provided in Table 9 and Map 2. 
Table 9. Overview of innovations substantiating the East Kikongo subgroup

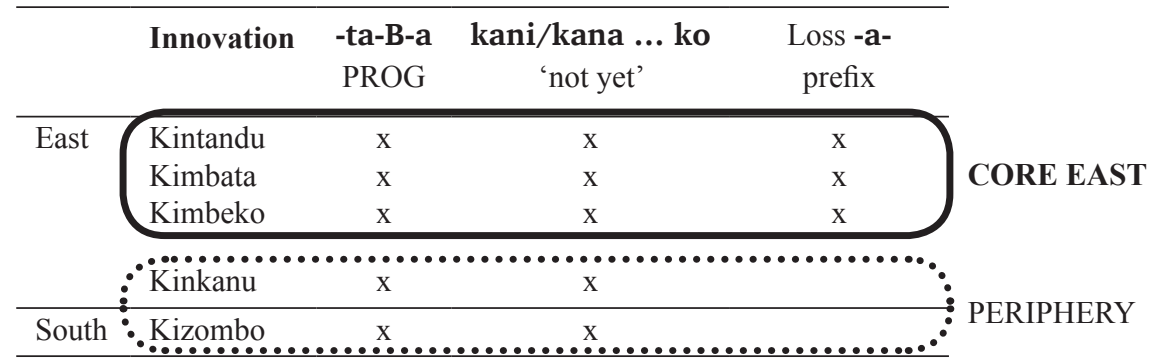

Map 2. Shared TA features whose distribution is restricted to the eastern part of the KLC. The colored dots refer to the phylogenetic subgroups represented on Map 1.

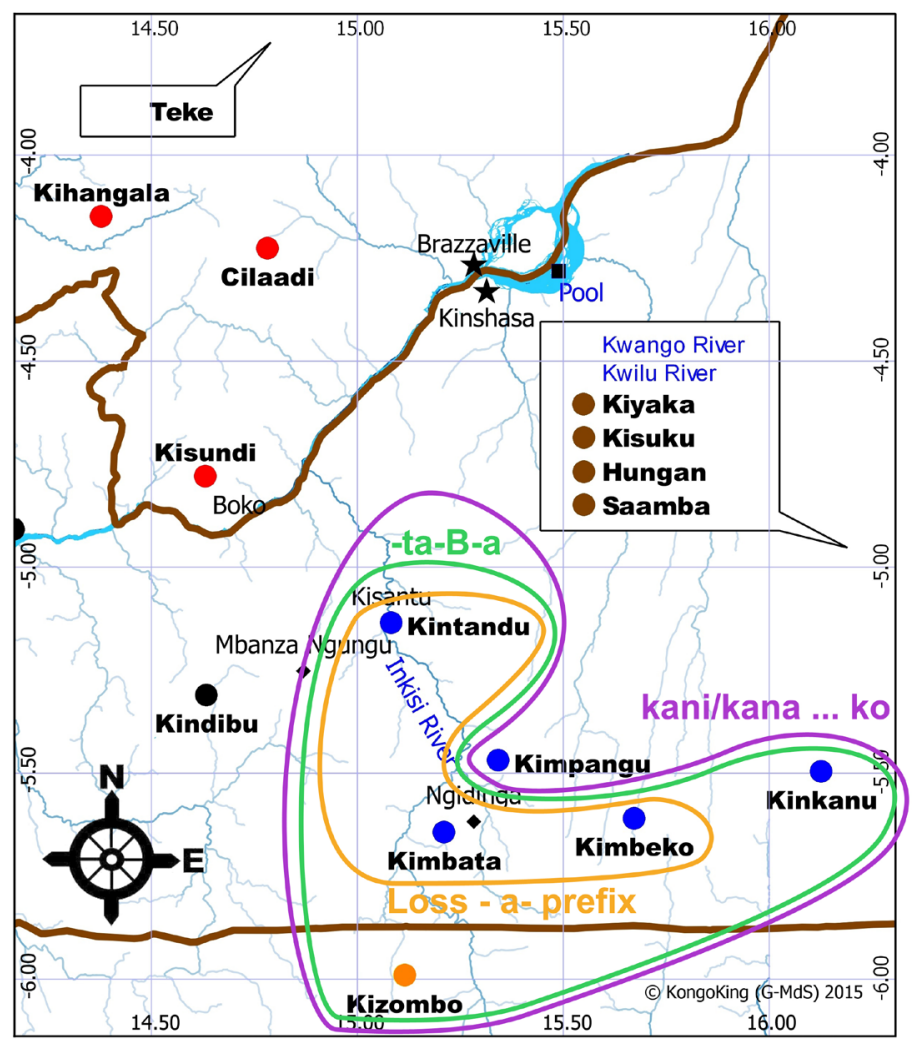




\subsubsection{South Kikongo}

The southern region of the KLC mainly comprises the northern parts of the Uige and Zaire provinces of Angola and the borderland between the DRC and Angola. Kikongo varieties spoken there are Kizombo, Kisikongo, Kisolongo, Dihungu and Kitsootso. The first three of them constitute, together with Kimboma (DRC), a discrete phylogenetic subgroup in the classification of de Schryver et al. (this volume); the latter two have not been considered by them. The only shared innovation corroborating the existence of a South Kikongo subgroup is the evolution of the "null" present into a zero future (cf. 3.1.11.). This feature is attested in Kisolongo, Kisikongo and Kizombo, but not in Kimboma. Bentley (1887:650) describes this innovation in $19^{\text {th }}$ century Kisikongo as the subjunctive future indefinite. However, the TA marker was at that time not yet a dedicated future marker, as it still expressed the present 'indefinite' (Bentley 1887:649). In an earlier stage of Kisikongo future time reference was expressed by the marker -ku-B-a. This marker is described in Brusciotto's 1659 grammar (Guinness 1882a:55), e.g. o-cu-zitiss-a 'you shall love', and is attested in a 1624 catechism (Cardoso 1624) translated from Portuguese in the southern Kikongo variety spoken at that time in Mbanza Kongo, the capital of the Kongo kingdom. This marker has been retained in the present-day southern varieties Dihungu and Kitsootso (cf. 3.1.12.). The zero future is not discussed in Brusciotto (Guinness 1882a) for $17^{\text {th }}$ century Kisikongo, and there are furthermore no attestations of the zero future in the 1624 catechism. By the end of the $19^{\text {th }}$ century, however, the "null" marker was clearly in an intermediate stage of becoming a dedicated future marker, as both its present and future meaning are described in Bentley (1887:649-50).

Furthermore, the fact that Kizombo is classified as South Kikongo on the basis of basic vocabulary, but shares historically significant TA innovations with both East and South Kikongo varieties indicates that the present-day language is partly the outcome of protracted contacts between both subgroups. It is situated between 'core' South (Kisikongo) and East (Kimbata) varieties. At present, our hypothesis is that all three South Kikongo varieties, i.e. Kisikongo, Kisolongo, and Kizombo, descend from a common ancestor, which we will call 'South Kikongo'. It has been shown that this historical variant must have been spoken at least three centuries ago (de Schryver et al. 2013), and was thus documented in Cardoso (1624) and Van Gheel (1652). The evolution of the zero marker from present to future probably took place in South Kikongo, and was subsequently inherited by Kisolongo, Kisikongo and Kizombo. In tandem with this, the habitual suffix -ang-developed into an imperfective marker. This innovation is inherited by Kisolongo, Kisikongo, and Kizombo spoken near Kisikongo, e.g. the one described in Carter \& Makondekwa (1987:23). Kizombo spoken more closely to the eastern Kimbata variety adopted the -ta- prefix from its northern neighbor. The present-day situation is concisely presented in Table 10 and on Map 3. 
Table 10. Overview of innovations substantiating the South Kikongo subgroup

\begin{tabular}{llcc}
\hline \multirow{4}{*}{ South } & Innovation & $\begin{array}{c}-\varnothing-\mathrm{C}-\mathbf{a} \\
\text { FUT }\end{array}$ & $\begin{array}{c}\text {-ku-B-a } \\
\text { FUT }\end{array}$ \\
& Kisikongo & $\mathrm{x}$ & \\
& Kisolongo & $\mathrm{x}$ & \\
& Kizombo & $\mathrm{x}$ & \\
\cline { 2 - 4 } & Kimboma ${ }^{16}$ & & \\
\hline \multirow{2}{*}{ Unclassified } & Kitsootso & & $\mathrm{x}$ \\
& Dihungu & & $\mathrm{x}$ \\
\hline
\end{tabular}

Map 3. Shared TA features whose distribution restricted to the southern part of the KLC. The colored dots refer to the phylogenetic subgroups represented on Map 1.

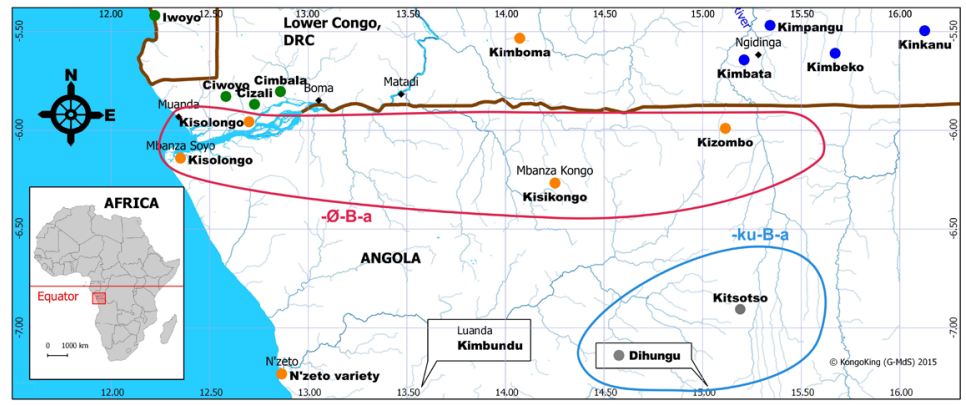

\subsubsection{West Kikongo}

The western part of the KLC seems to be the most innovative one in terms of TA morphology, resulting in quite a complex situation.

The inceptive prefix -eka- has the widest distribution (cf. 3.1.4.), covering Kisundi and Kiyombe spoken in the interior as well as Iwoyo, Ciwoyo and Cizali spoken in the Congo delta. It is the only feature which Kisundi shares with these other varieties. Given that Kisundi belongs to the North subgroup in the classification of de Schryver et al. (this volume), while the others cluster together as West, the adoption of -eka- in Kisundi could be contact-induced. A phonologically similar prefix with the related meaning 'imminent' or 'near' future is attested in the B40 languages Isangu and Yipunu. If this prefix is indeed cognate to -eka- in the West Kikongo varieties further north, it can be considered a shared morphological innovation that corroborates the unity of the phylogenetic West Kikongo subgroup, just like possibly the -i- present marker attested in Ciwoyo, Iwoyo and Yipunu (cf. 3.1.10.). The marker -eka- is also described in Carrie's (1888:86) grammar of the western Kikongo variety spoken in Kakongo, but not in the one by Cuénot (1776). In the latter grammar (Cuénot 1776:38) as well as in Carrie (1888:86), a

16. According to Kisilu Meso (2001:45), the future in Kimboma is expressed by the TA prefix -na-, e.g. ngi-na-vov-a 'I will speak'. 
present marker -li- is described which is possibly cognate to the present marker -iattested in present-day West Kikongo varieties. The perfect marker -ma- (cf. 3.1.6.) is another innovation shared between the West Kikongo H10 and B40 languages, but this is most likely an independent or contact-induced innovation, as we argue below. All other innovations within West Kikongo rather point towards a clear split in this subgroup between a northern (B40) and a southern (H10) cluster. The unity of the northern cluster is substantiated by one specific shared TA innovation, i.e. the perfect marker -tsV- (cf. 3.1.13). The other West Kikongo innovations concern the southern cluster.

The future tense innovations, viz. the formative -ala- and the auxiliary -kwiza 'come', are not attested in Kisundi, but both shared between Kiyombe, Iwoyo, Ciwoyo and Cizali (cf. 3.1.5.). They indicate that the southern H10 languages constitute a discrete cluster within the phylogenetic West Kikongo subgroup, as de Schryver et al. (this volume) also claim on the basis of basic vocabulary. The future prefix -ala- is furthermore attested in a 1776 grammar of the western Kikongo variety spoken in Kakongo (Cuénot 1776:41), e.g. i-ala-li-a 'I will eat'. Within that southern subgroup of West Kikongo, the most innovative varieties seem to be the coastal varieties Iwoyo (Cabinda) and Ciwoyo (DRC) as far as its data stretch. They manifest innovations which they share with some other West Kikongo varieties, but not with all. The perfect marker -ma- is found in Kiyombe, Iwoyo and Ciwoyo, but not in Cizali (cf. 3.1.6.), whereas the spirantized reflex of *-ide is attested in Cizali, Civili, Iwoyo and Ciwoyo, but not in Kiyombe (cf. 3.1.7.). It is important to note that the auxiliary -mana 'finish' or its perfect form -mene is presented as a marker of the "prétérit parfait" in the grammar of Cuénot (1776:40), which describes the West-Kikongo variety as spoken in Kakongo. No grammaticalized formative -ma- is attested in this source. This seems to indicate that the perfect -ma- is probably not a shared innovation inherited from the most recent common ancestor of the West Kikongo subgroup, but rather an innovation having occurred after the break-up of proto-West Kikongo into two branches, either independently or through contact between both branches. Furthermore, Kiyombe, Iwoyo and Ciwoyo are the only three varieties who have undergone a reshuffling of the past tense markers at the expense of the complex final -izingi in Iwoyo and Ciwoyo, which has been retained in Cizali and Kiyombe (cf. 3.1.8.). The distribution of the present marker -i- is also restricted to Iwoyo, Ciwoyo and Yipunu.

Taking into account the phylogenetic classification by de Schyver et al. (this volume), the distribution of this set of TA innovations as well as the geographical location of these varieties, Kisundi can best be considered as a North Kikongo variety which underwent some contact-induced TA influence from West Kikongo. The belonging of Kiyombe and Cizali to West Kikongo is confirmed, but both varieties are more conservative in certain TA respects than the coastal varieties Ciwoyo and Iwoyo (as far as the sparse descriptive data on the latter language allow to judge). Table 11 gives a summary of the relevant markers and their distribution within the KLC. The most important isoglosses are shown on Map 4. Note that the B40 languages are not represented separately on Map 4, and the distribution of some features found in only two of the three B40 languages is therefore not illustrated completely. 
Table 11. Overview of innovations substantiating the West Kikongo subgroup

\begin{tabular}{|c|c|c|c|c|c|c|c|c|c|}
\hline & Innovation & -eka- & FUT & -izi & shift PST & $-\mathrm{ma}-$ & -eta/eti- & $-i-$ & -tsV- \\
\hline North & Kisundi & $\mathrm{x}$ & & & & & $\mathrm{x}$ & & \\
\hline \multirow[t]{7}{*}{ West } & Cizali & $\mathrm{x}$ & $\mathrm{x}$ & $\mathrm{x}$ & & & & & \\
\hline & Kiyombe & $\mathrm{x}$ & $\mathrm{x}$ & & $\mathrm{x}$ & $\mathrm{x}$ & $\mathrm{x}$ & & CORE \\
\hline & Ciwoyo & $\mathrm{x}$ & $\mathrm{x}$ & $\mathrm{x}$ & $\mathrm{x}$ & $\mathrm{x}$ & $\mathrm{x}$ & $\mathrm{x}$ & WEST \\
\hline & Iwoyo & $\mathrm{x}$ & $\mathrm{x}$ & $\mathrm{x}$ & $\mathrm{x}$ & $\mathrm{x}$ & & $\mathrm{x}$ & \\
\hline & Yipunu & $\mathrm{x}$ & & & & $\mathrm{x}$ & & $\mathrm{x}$ & $\mathrm{x}$ \\
\hline & Isangu & $\mathrm{x}$ & & & & $\mathrm{x}$ & & & $\mathrm{x}$ \\
\hline & Yilumbu & & & & & $\mathrm{x}$ & & & $\mathrm{x}$ \\
\hline Central & Kimanyanga & & & & & & $\mathrm{x}$ & & \\
\hline South & Kimboma & & & & & & $\mathrm{x}$ & & \\
\hline
\end{tabular}

Map 4. Shared TA features whose distribution is restricted to the western(-central) part of the KLC. The colored dots refer to the phylogenetic subgroups represented on Map 1.

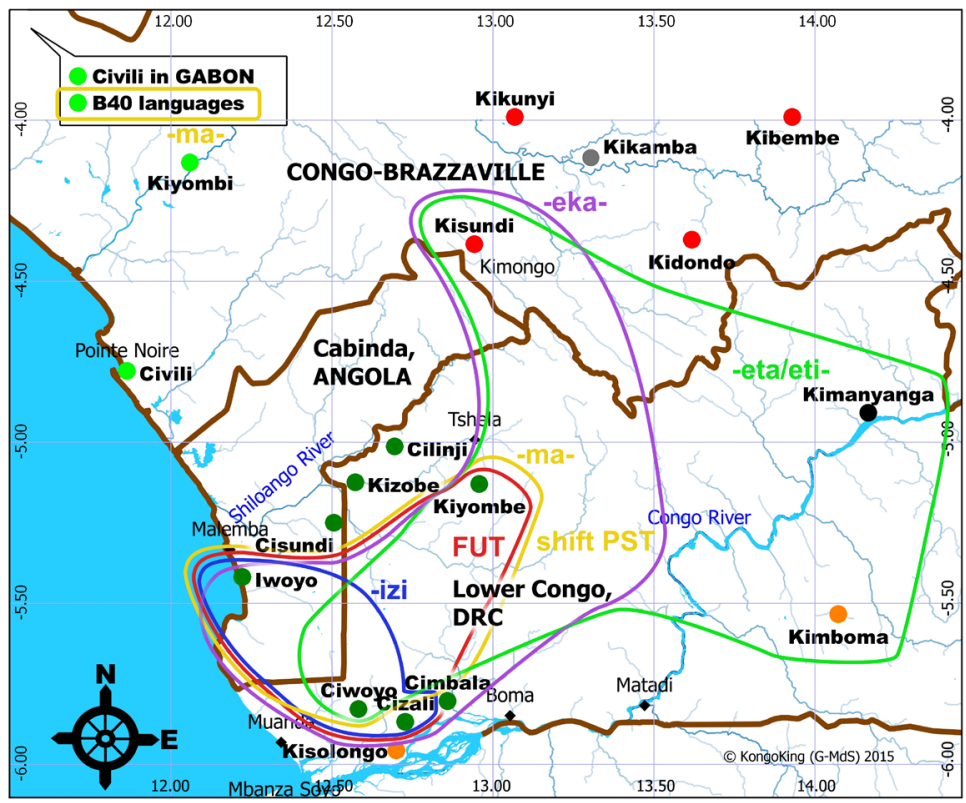




\subsubsection{North Kikongo}

The picture that arises from a comparison of the TA systems of the varieties located in the northern part of the KLC is one of high diversity. We could not identify shared innovations that corroborate their classification as a discrete North subgroup by de Schryver et al. (this volume). Apart from a general lack of good descriptive data on the TA systems of Kikunyi, Kidondo, Kihangala and Cilaadi, there is too much variation to generate a significant subgrouping. The best described varieties in terms of TA, i.e. Kibembe and Kikamba, have clearly developed some innovative TA markers which do not occur in the other Kikongo varieties, such as the progressive marker -kwe- in Kibembe (Kouarata 2015:113-14) or the compound future formative -abwe- in Kikamba (Bouka 1989: no page numbers).

As presented in 3.1.14., Kibembe and Kikamba, two neighboring varieties spoken in the RC, share one TA innovation, i.e. the present marker -(a)ko-. However, the sharing of one innovative feature does not allow establishing a discrete subgroup. More information is needed in order to consistently compare the TA morphology of the northern Kikongo varieties.

\subsubsection{Central Kikongo}

De Schryver et al. (this volume) do not consider Central Kikongo as a true subgroup but rather as a large contact zone. We also could not identify TA innovations that would be indicative of a genealogical Central subgroup. This is not surprising, since we only considered Kimanyanga here for lack of a description of the TA system in Kindibu, the other Central variety. The only significant TA isogloss involving Kimanyanga is the present prefix -eti-/-eta-, which it shares with the West Kikongo varieties Kiyombe, Cizali and Ciwoyo, the North Kikongo variety Kisundi and the South Kikongo variety Kimboma. This TA marker is thus prevalent in West Kikongo and further attested in three Kikongo varieties each belonging to three different subgroups. This could point towards contact-induced influence of West Kikongo on different varieties spoken in the interior.

\section{Conclusion}

The study of variation in the expression of tense and aspect in several varieties belonging to Guthrie's H10, H30 and B40 languages presented in this article has led to significant new insights on the historical evolution of the KLC. Some of these match with the phylogenetic classification of de Schyver et al. (this volume). Others are rather at odds with it, because they point either towards another genealogy or towards parallel or contact-induced evolutions that have interfered with the initial language divergence, which the phylogenetic tree attempts to model.

Not fewer than eight widespread TA features can be reconstructed to a very early stage of the KLC. At least six of them were inherited from Proto-Bantu or certainly from an ancestor that is older than the most recent common ancestor of the KLC. Two of them seem to be later innovations that possibly corroborate the genealogical status of the KLC as a discrete clade within West-Coastal Bantu (cf. de Schryver et al. this volume). One of these innovative markers, i.e. the compound past suffix 
-idingi, occurs in the different phylogenetic subgroups of the KLC as well as in Kikongoid languages, such as Kiyaka. The other, i.e. the preverbal future marker si, occurs in all core KLC subgroups, but not in the Kikongoid languages. This future marker could be a later innovation than the compound past marker, indicating that the Kikongoid languages did indeed branch off before the internal fragmentation of the core KLC subgroups started. In this respect, both morphological innovations nicely match with distinct nodes in the lexically based phylogenetic tree. The future marker si is reconstructable to Proto-Kikongo, while the past marker -idingi can be reconstructed to Proto-Kikongoid. There is also an important, but possibly only apparent, mismatch at this level, i.e. the B40 languages. While these southern Gabonese languages are an integral part of one of the KLC's core phylogenetic subgroups, i.e. West Kikongo, they have none of both shared innovations. Although this could be taken as evidence for their genealogical classification outside the $\mathrm{KLC}$, it cannot be excluded that they lost both in a later stage of their evolution. The fact that the B40 languages share almost no Proto-Bantu retentions with the rest of the KLC could indicate that their TA systems did indeed undergo strong innovation.

Fourteen TA features discussed in this article are the outcome of changes that took place posterior to Proto-Kikongo. As far as the available data allow to judge, some of them corroborate (parts of) the previously established phylogenetic subgroups, while others are rather indicative of interferences between subgroups due to contact-induced change.

The subgroup less well corroborated by the TA evidence presented here is no doubt North Kikongo. We could not identify a single innovation that is shared by more than two North Kikongo varieties and not by any other Kikongo variety. More TA data are needed to examine whether this is an artifact of the currently available documentation or whether more is going on.

The subgroup best confirmed in its entirety is definitely East Kikongo. The Inkisi River to the east of which all these varieties are spoken clearly constitutes an important natural language border. Kintandu, Kimbata and Kimbeko, the westernmost varieties which share three characteristic TA innovations, seem to constitute the core of that subgroup. The more peripheral Kinkanku, which is spoken closer to the Kwango region, missed out one of these. Two of these innovations also occur in Kizombo which phylogenetically does not belong to East Kikongo, but to South Kikongo. Given that Kizombo also shares characteristic TA innovations with other South Kikongo varieties, the occurrence of these East Kikongo TA features can be best explained by substantial contact-induced East Kikongo interference in Kizombo. Such horizontal transmission of TA features may have well been favored by certain specific historical circumstances in which this eastern South Kikongo variety was used, such as the involvement of its speakers in pre-colonial interregional trade networks. The Bazombo used to be important middlemen in the long-distance trade, especially slave traffic, between the Atlantic coast and the central provinces of the Kongo kingdom, where South Kikongo was spoken, and the north-eastern provinces of the kingdom, where East Kikongo prevailed. A historically well-known caravan route connecting the coastal region around Luanda with the eastern Kwango region was even called nzila Bazombo or the Bazombo trail (Van Wing 1921:108). 
The South Kikongo subgroup is less well corroborated by shared innovations in the TA system. The three core varieties Kisikongo, Kisolongo, and Kizombo only share one characteristic semantic shift, i.e. the evolution of the zero present conjugation into a dedicated future marker. Neither the Kimboma variety spoken in the DRC and classified as South Kikongo by de Schryver et al. (this volume) nor Kitsootso and Dihungu spoken further south partook in that innovation.

Most shared TA innovations indicative of common descent have undoubtedly been observed in West Kikongo. The varieties spoken along the Atlantic coast north of the Congo mouth, i.e. Ciwoyo and Iwoyo, happen to have innovated their TA system most extensively. This coastal stretch was home to several small kingdoms, such as Kakongo, Ngoyo and Loango and used to be pivotal in the trade connecting its hinterland with the Trans-Atlantic world (Martin 1972, Mulinda 1993, Proyart 1776, Volavka 1998). It is therefore likely to have constituted an important center of linguistic and other innovations. Trade between the coast and the interior probably also accounts for the fact that West Kikongo TA features are found in Kikongo varieties further east belonging to different phylogenetic subgroups. Long-distance trade routes for caravans manned and directed by coastal people, such as the Vili from Loango, linked the coast north of the Congo mouth with the interior, especially the borderlands of the Kongo kingdom north of the river (Hilton 1985, Martin 1972, Vansina 1962). In the phylogenetic classification, the north-western B40 varieties cluster together with a series of more southern H10 Kikongo varieties to constitute a discrete West Kikongo subclade. However, they still remain a distinct subgroup within that subclade. One innovation shared by Yipunu, Isangu and Yilumbu only, viz. the perfect marker -tsV-, corroborates their separate position within West Kikongo. The southern West Kikongo varieties Ciwoyo, Iwoyo, Kiyombe and Cizali also share TA innovations confirming their status as a subgroup within West Kikongo. The corroboration of the genetic unity of West Kikongo as a whole on the basis of TA morphology is less obvious. The perfect prefix -ma- is an innovation found in all B40 and several West Kikongo H10 varieties considered here. However, as argued above, it may have independently grammaticalized from the verb -mana 'finish', which is still found as an auxiliary for the perfect in the West Kikongo variety spoken in Kakongo at the end of the $18^{\text {th }}$ century. The best evidence for the time being substantiating the hypothesis of more recent common ancestry is the inceptive-near future marker -eka-. It is shared by Ciwoyo, Iwoyo, Kiyombe, Cizali, Yipunu, Isangu and Kisundi, but its presence in this latter North Kikongo variety neighboring several West Kikongo varieties could well be contact-driven.

The contact-induced transmission of language features also contributed to the emergence of a Central Kikongo contact zone that straddles the Congo river and is situated in the periphery of several important polities and at the junction of different regional trade networks. We could adopt here the term 'catch basin', which Seidel (2009) uses to characterize the contact-induced hybridization at the multi-linguistic origin of Yeyi (R41). According to de Schryver et al. (this volume), such horizontal transmission of language features was most formative in the emergence of the Kimanyanga and Kindibu varieties. They seem to have 'caught' innovative basic vocabulary from enough different subgroups to be classified as a separate subgroup 
in the phylogenetic tree. The TA evidence considered here points out that not only Kimanyanga, but also neighboring varieties, such as Kimboma (South) and Kisundi (North), adopted innovations that originated in other subgroups. This suggests that even the Central Kikongo 'catch basin' may have a core and a periphery.

In addition to the phylogenetic and lexically based approach by de Schryver et al. (this volume), which primarily focused on language divergence with the KLC, our classical comparative linguistic approach of one specific grammatical domain has highlighted, as previous studies did (Bostoen et al. 2013, Bostoen \& de Schryver 2015), that language convergence is also an important formative factor to be taken into account in order to come to a better understanding of the layered constitution of the KLC. Our TA-based classification serves as one more level in a multi-level approach of the genesis and evolution of the KLC. Comparisons based on different aspects of language, i.e. phonology, morphology (of the nominal and verbal domain besides TA), lexicon and syntactic structures need to be superimposed to enable a dynamic interpretation of micro-variation. Only then will we be equipped to study how language variation in the KLC correlates with variations in the natural environment and in other domains of human life, such as material culture, as well as with certain historical developments that have shaped the Lower Congo region. This will eventually lead to a better understanding of how language change is conditioned by the outside world.

\section{Acknowledgments}

Thanks go to Heidi Goes, Birgit Ricquier and two anonymous reviewers for their comments on an earlier draft of this article as well as to Gilles-Maurice de Schryver for comments and maps, and Elie Verbrugge for drawing the isoglosses. The usual disclaimers apply.

\section{Abbreviations}

$\begin{array}{ll}\text { ADV } & \text { adverb } \\ \text { APPL } & \text { applicative } \\ \text { AUG }_{x} & \text { augment, number of class in subscript (here indicated by ' } \mathrm{x} \text { ') } \\ \text { B } & \text { verb base } \\ \text { CON } & \text { connective } \\ \text { DEM }_{\mathrm{x}} & \text { demonstrative } \\ \text { F/FUT } & \text { future } \\ \text { FV } & \text { final vowel } \\ \text { GEN } & \text { generic } \\ \text { HAB } & \text { habitual } \\ \text { INC } & \text { inceptive } \\ \text { IPFV } & \text { imperfective } \\ \text { KLC } & \text { Kikongo Language Cluster } \\ \text { LOC } & \text { locative } \\ N & \text { nasal } \\ N & \text { homorganic nasal }\end{array}$




$\begin{array}{ll}\text { NEG } & \text { negative } \\ \text { NP }_{x} & \text { nominal prefix } \\ \text { OM }_{x} & \text { object marker } \\ \text { P/PST } & \text { past } \\ \text { PASS } & \text { passive } \\ \text { PL } & \text { plural } \\ \text { POSS }_{x} & \text { possessive } \\ \text { PP }_{x} & \text { pronominal prefix } \\ \text { PRED }_{\text {PRF }} & \text { non-verbal predicate } \\ \text { PROG } & \text { perfect } \\ \text { PRON } & \text { progressive } \\ \text { PRS } & \text { pronoun } \\ \text { Q } & \text { present } \\ \text { RECP } & \text { question particle } \\ \text { REFL } & \text { reciprocal } \\ \text { REM } & \text { reflexive } \\ \text { SG } & \text { remote } \\ \text { SM } & \text { singular } \\ & \text { subject marker }\end{array}$

\section{References}

Atkins, G. 1954. 'An outline of Hungu grammar'. Garcia de orta 2: 145-164.

Baka, J. 1992. 'Essai de description du tso:tso, parler ko:ngo du Nord de l'Angola'. $\mathrm{PhD}$ dissertation, Université libre de Bruxelles, Bruxelles.

Bastin, Y. 1983. La finale verbale -IDE et l'imbrication en bantou. Tervuren: Royal Museum for Central Africa.

Bastin, Y. 1989a. 'El prefijo locativo de la classe 18 y la expressión del progresivo presente en bantu (1)'. Estudias africanos: revista de la Asociación Española de Africanistas 4,6: 35-55.

Bastin, Y. 1989b. 'El prefijo locativo de la classe 18 y la expressión del progresivo presente en bantu (2)'. Estudias africanos: revista de la Asociación Española de Africanistas 4,7: 61-86.

Bastin, Y. 2006. 'Un PV ị- à la première personne du singulier en bantou'. Africana Linguistica 12: 25-36.

Bastin, Y., Coupez, A., Mumba, E. \& Schadeberg, T.C. (eds). 2002. Bantu Lexical Reconstructions 3 / Reconstructions lexicales bantoues 3. Tervuren: Royal Museum for Central Africa. Online at http://www.africamuseum.be/collections/ browsecollections/humansciences/blr.

Bentley, W.H. 1887. Dictionary and grammar of the Kongo language as spoken at San Salvador, the ancient capital of the old Kongo empire, West Africa. London: Baptist Missionary Society and Trübner \& Co.

Bittremieux, L. 1927. Mayombsch idioticon, Deel III: Verbeteringen en Aanvullingen, Plantenkundige Woordenlijsten en Zakenregister (Congo-Bibliotheek 21). Bruxelles: Drukkerij Essorial.

Bonneau, J. 1956. Grammaire pounoue et lexique pounou-français. Brazzaville: Imprimerie Charité. 
Bostoen, K. 2008. 'Bantu Spirantization: Morphologization, lexicalization and historical classification'. Diachronica 25,3: 299-356.

Bostoen, K. \& de Schryver, G.-M. 2015. 'Linguistic innovation, political centralization and economic integration in the Kongo kingdom: Reconstructing the spread of prefix reduction'. Diachronica 32,2: 139-85 +13 pages of supplementary material online.

Bostoen, K., Ndonda Tshiyayi, O. \& de Schryver, G.-M. 2013. 'On the origin of the royal Kongo title ngangula'. Africana Linguistica 19: 53-83.

Botne, R. 2006. 'Motion, time, and tense: On the grammaticization of come and go to future markers in Bantu'. Studies in African Linguistics 35,2: 127-188.

Botne, R. 2014. 'Resultatives, remoteness, and innovation in Eastern and Southern Bantu T/A systems'. Nordic Journal of African Studies 23,1: 16-30.

Botne, R. \& Kershner, T.L. 2008. 'Tense and cognitive space: On the organization of tense/aspect systems in Bantu languages and beyond'. Cognitive Linguistics 19,2: 145-218.

Bouka, L.Y. 1989. 'Éléments de description du kaamba, parler bantou de la République populaire du Congo (Groupe Koongo, H17b)'. PhD dissertation, Université libre de Bruxelles, Bruxelles.

Brisard, F. \& Meeuwis, M. 2009. 'Present and perfect in Bantu: The case of Lingála'. Journal of African Languages and Linguistics 30: 21-43.

Butaye, S.J. 1910. Grammaire congolaise. Roulers: Jules De Meester.

Bybee, J., Perkins, R. \& Pagliuca, W. 1994. The evolution of grammar: Tense, aspect, and modality in the languages of the world. Chicago: The University of Chicago Press.

Cardoso, M. 1624. Doutrina Christaã, Composta pelo P. Marcos Iorge da Companhia de Iesu Doutor em Theologia. Acrescentada pelo Padre Ignacio Marinz da Mesma Companhia Doutor Theologo. De nouo traduzida na lingoa do Reyno de Congo, por ordem do P. Mattheus Cardoso Theologo, da Companhia de Iesu, natural da cidade de Lisboa. Ao muito poderso, \& catholico Rey de Congo dom Pedro Affonso Segundo deste nome. Lisbon: Geraldo da Vinha.

Carrie, (Monseigneur). 1888. Grammaire de la langue fiote, dialecte du Kakongo. Loango: Imprimerie de la Mission.

Carter, H. \& Makondekwa, J. 1987. Kongo language course: Maloongi makikoongo, a course in the dialect of Zoombo, Northern Angola. Madison: African Studies Program, University of Wisconsin.

Comrie, B. 1985. Tense. Cambridge: Cambridge University Press.

Cuénot. 1776. Essai d'une grammaire Congo suivant l'accent de Kakongo. Besançon: Bibliothèque municipale de Besançon, Manuscrit $\mathrm{n}^{\circ} 523$.

Cysouw, M. \& Good, J. 2013. 'Languoid, doculect, glossonym: Formalizing the notion "language"'. Language Documentation \& Conservation 7: 331-59.

Daeleman, J. 1966. 'Morfologie van naamwoord en werkwoord in het Kongo (Ntandu) met ontleding van het foneemsysteem'. PhD dissertation, Katholieke Universiteit Leuven, Leuven.

Dahl, Ö. 1985. Tense and aspect systems. Oxford: Basil Blackwell.

De Clercq, L. 1921. Grammaire du kiyombe. Brussels: Goemare. 
De Kind, J., Dom, S., de Schryver, G.-M. \& Bostoen, K. 2012. Documenting variation in the Kikongo dialect cluster: Report on the 2012 fieldwork in the Lower Congo Province (DRC). Paper presented at 6th Symposium of the Ghent Africa Platform (GAPSYM6), Ghent.

De Kind, J., Dom, S., de Schryver, G.-M. \& Bostoen, K. 2015. 'Event-centrality and the pragmatics-semantics interface in Kikongo: From predication focus to progressive aspect and vice versa'. Folia Linguistica Historica 36: 113-63.

de Schryver, G.-M., Grollemund, R. \& Bostoen, K. 2013. A diachronic phylogenetic approach to the internal classification of the Kikongo group. Paper presented at the $43^{\text {rd }}$ Colloquium on African Languages and Linguistics, Leiden.

Dom, S. 2013. 'Tijd en aspect in Kikongo (Bantoe H16): Een comparatieve benadering van het Kimbata, Kimbeko, Kinkanu, Cizali, Ciwoyo en Kisolongo’. MA dissertation, Ghent University, Ghent.

Gamille, L.G. 2013. 'Éléments de description phonologique et morphologique de Lumbu, langue bantu (B44) du Gabon parlée à Mayumba'. PhD dissertation, Université de la Sorbonne nouvelle - Paris III, Paris.

Guinness, H.G. (ed.). 1882a. Grammar of the Congo language as spoken two hundred years ago, translated from the Latin of Brusciotto. London: Hodder \& Stoughton.

Guinness, H.G. 1882b. Grammar of the Congo language as spoken in the Cataract region below Stanley Pool. London: Hodder and Stoughton.

Güldemann, T. 2003. 'Present progressive vis-à-vis predication focus in Bantu: A verbal category between semantics and pragmatics'. Studies in Language 27,2: 323-360.

Guthrie, M. 1971. Comparative Bantu 2. London: Gregg Press.

Hadermann, P. 1996. 'Grammaticalisation de la structure Infinitif + Verbe conjugué dans quelques langues bantoues'. Studies in African Linguistics 25,2: 155-170.

Haspelmath, M. 1998. 'The semantic development of old presents: New futures and subjunctives without grammaticalization'. Diachronica 15,1: 29-62.

Herbert, R.K. 1986. Language universals, markedness theory, and natural phonetic processes. Berlin: Mouton de Gruyter.

Hilton, A. 1985. The Kingdom of Kongo. Oxford; New York, NY: Clarendon Press; Oxford University Press.

Hyman, L.M. 1999. 'The historical interpretation of vowel harmony in Bantu'. In J.-M. Hombert \& L.M. Hyman (eds), Bantu Historical Linguistics: Theoretical and empirical perspectives (CSLI Lecture Notes 99). Stanford, CA: Center for the Study of Language and Information, pp. 235-295.

Hyman, L. 2003. 'Segmental phonology'. In D. Nurse \& G. Philippson (eds), The Bantu languages, London: Routledge, pp. 42-58.

Idiata, D.F. 2006. Parlons isangu: Langue et culture des Bantu-Masangu du Gabon. Paris: L'Harmattan.

Jacquot, A. 1982. 'Étude descriptive de la langue laadi'. PhD dissertation, Université de Lille, Lille.

Kerremans, R. 1980. 'Nasale suivie de consonne sourde en proto-bantu'. Africana Linguistica 8: 159-198. 
Kipacha, A. 2006. 'The impact of the morphological alternation of subject markers on tense/aspect: The case of Swahili'. ZAS Papers in Linguistics 43: 81-96.

Kisilu Meso, J.S. 2001. 'Morphologie flexionelle du kimboma'. Mémoire de licenciée, Institut Pédagogique National, Kinshasa.

Kitambika, N. 1994. 'Éléments de description du kisuundi (H13b), parler de la République du Congo'. Mémoire de licence spéciale, Université libre de Bruxelles, Bruxelles.

Kouarata, G.N. 2015. Grammaire beembe. Langue bantu (H10) du Congo-Brazzaville. Paris: Edilivre.

Laman, K.E. 1912. Grammar of the Kongo language (Kikongo). New York: Christian Alliance Publishers.

Laman, K.E. \& Meinhof, C. 1928-29. 'An essay in Kongo phonology'. Zeitschrift für Eingeborenen-Sprachen 19: 12-40.

Lewis, M.P., Simons, G.F. \& Fennig, C.D. (eds). 2014. Ethnologue: Languages of the world, seventeenth edition. Dallas, Texas: SIL International. Online version. URL: http://www.ethnologue.com/. (31/01/2015).

Lumwamu, F. 1973. Essai de morphosyntaxe systématique des parlers kongo. Paris: Éditions Klincksieck.

Mabiala, J.-N. 1999. 'Phonologie comparative et historique du koongo'. $\mathrm{PhD}$ dissertation, Université Lumiere Lyon 2, Lyon.

Maho, J.F. 2009. NUGL Online: The online version of the new updated Guthrie list, a referential classification of the Bantu languages. Retrieved from http://goto. glocalnet.net/mahopapers/nuglonline.pdf.

Makokila Nanzanza, A. 2012. 'Le système verbal du kimanyaanga: Approche structuraliste'. Mémoire DEA, Université de Mbuji-Maji, Mbuji-Maji.

Martin, P. 1972. The external trade of the Loango Coast, 1576-1870: The effects of changing commercial relations on the Vili Kingdom of Loango. Oxford: Clarendon Press.

Meeussen, A.E. 1962. 'Meinhof's Rule in Bantu'. African Language studies 3: 25-29.

Meeussen, A.E. 1967. 'Bantu grammatical reconstructions'. Africana Linguistica 3: 79-121.

Mingas, A.A. 1994. 'Étude grammaticale de l'iwoyo (Angola)'. PhD dissertation, Université René Descartes Paris, Paris.

Mpanzu, L. 1994. 'Éléments de description du zombo, parler kongo H16k d'Angola'. Mémoire de licence spéciale, Université libre de Bruxelles, Bruxelles.

Mulinda, H.B. 1993. 'Aux origines du royaume de Ngoyo'. Civilisations 41: 165-186.

Ndonga Mfuwa, M. 1995. 'Systématique grammaticale du kisikongo (Angola)'. PhD dissertation, Université René Descartes, Paris.

Nsayi, B. 1984. 'Approche du kibeembe: Première et deuxième articulation'. PhD dissertation, Université René Descartes, Paris.

Ntunda Nzeza, W. 2007. 'La variation dialectale Koongo: Essai de classification des parlers Koongo en République Démocratique du Congo'. PhD dissertation, Université de Kinshasa, Kinshasa.

Nurse, D. \& Philippson, G. 2006. 'Common tense-aspect markers in Bantu'. Journal of African Languages and Linguistics 27: 155-196. 
Nurse, D. 2008. Tense and aspect in Bantu. Oxford: Oxford University Press.

Ondo-Mebiame, P. 2000. Essai de description morphophonologique du Yisangu, langue bantu du Gabon. Munich: LINCOM Europa.

Proyart, L.B. 1776. Histoire de Loango, Kakongo, et autres royaumes d'Afrique;

Rédigée d'après les Mémoires des Préfets Apostoliques de la Mission françoise; enrichie d'une Carte utile aux Navigateurs. Paris; Lyon: C.P. Berton \& N. Crapart; Bruyset-Ponthus.

Schadeberg, T.C. 1995. 'Spirantization and the 7-to-5 vowel merger in Bantu'. Belgian Journal of Linguistics 9: 71-84.

Sebasoni, S. 1967. 'La préfinale du verbe bantou'. Africana Linguistica 3: 123-135.

Seidel, F. 2009. 'Layered language genesis in the 'catch basin' of the Linyanti and Okavango swamps: The case of Yeyi'. Sprache und Geschichte in Afrika 20: 231-264.

Tucker, A.N. 1974. 'Questionnaire pour les langues bantu et non-bantu'. In G. Manessy \& J.M.C. Thomas (eds), Les langues sans tradition écrite. Méthodes d'enquête et de description, Actes du Colloque International du CNRS, Nice, 28 juin-2 juillet 1971. Paris: SELAF, pp. 49-74.

Van Den Eynde, K. 1968. 'Éléments de grammaire yaka: phonologie et morphologie flexionelle'. PhD dissertation, Université Lovanium, Publications Universitaires, Kinshasa.

Van Gheel, J. 1652. Vocabularium Latinum, Hispanicum, e Congense. Ad Usum Missionariorû transmittendorû ad Regni Congo Missiones. Manuscript kept in the National Central Library of Rome: Fundo Minori 1896, MS Varia 274.

Van Wing, J. 1921. Etudes Bakongo, Histoire et Sociologie. Bruxelles: Goemare.

Vansina, J. 1962. 'Long-distance trade-routes in Central Africa'. Journal of African History 3: 375-390.

Volavka, Z. 1998. Crown and ritual: The royal insignia of Ngoyo. Toronto/London: University of Toronto Press.

\section{Authors' addresses}

Sebastian Dom

KongoKing Research Group

Department of Languages and Cultures: Africa

Ghent University

Rozier 44

9000 Gent

sebastian.dom@UGent.be

Koen Bostoen

KongoKing Research Group

Department of Languages and Cultures: Africa

Ghent University

Rozier 44

9000 Gent

koen.bostoen@UGent.be 


\section{Résumé}

Dans cet article, nous étudions les variations de l'expression du temps et de l'aspect (TA) dans 23 variétés modernes et deux variétés anciennes de langues bantus appartenant aux groupes B40, H10 et H30 de la classification de Guthrie, afin de jeter une lumière nouvelle sur la classification interne du groupe linguistique kikongo que nous appelons le Kikongo Language Cluster (KLC). Nous appliquons la méthode comparative à cet ensemble spécifique de données morphologiques afin de tester une classification phylogénétique récente du KLC. Nous identifions huit marqueurs TA largement répandus comme des rétentions partagées datant d'avant la fragmentation interne du KLC. Six d'entre eux sont hérités du proto-bantu, les deux autres remontent au proto-kikongoïde et au proto-kikongo. Ils confirment que le KLC constitue un clade distinct au sein de la branche dite «West-Coastal» du bantu. En outre, nous distinguons quatorze innovations partagées datant d'après l'éclatement du dernier ancêtre commun du KLC. Ces innovations fournissent des éléments corroborant l'existence de trois sous-groupes phylogénétiques du KLC, à savoir Est, Sud et Ouest, et suggérant que ce dernier se scinde en deux sous-unités généalogiques distinctes. Elles témoignent en outre d'une transmission horizontale des traits TA entre les sous-groupes. Une telle convergence linguistique va souvent de pair avec des développements historiques relativement récents opérés au sein de la région du Bas-Congo et a contribué à la formation multicouche du KLC. 